\title{
THE DEBTOR'S INTEREST IN PERSONAL PROPERTY UNDER THE PPSA
}

\section{BRUCE MACDOUGALL •}

The PPSA legislation in this country allows various individuals to hold interests in personal property without having possession of that property. In this way it negates the traditional principle of equating an interest strictly with possession. In this article, the author explores the interests established by the PPSAs specifically in relation to the debtor. One problem noted is the tendency of the PPSAs to use the terms "interest" and "right" interchangeably with respect to the debtor in some areas, and to draw a distinction between the terms in others. The author examines the distinction between these terms at length, and suggests that "interest" would be a more appropriate term to use in the legislation.

Also discussed is what factors are necessary in order for the debtor to create a "sufficient" interest in the personal property in question. Information here comes largely from case law, as the legislation itself is not specific. As a result, some uncertainty exists as to which factors create a sufficient interest for the debtor, particularly as to whether or not certificates of title or production quotas or licences held by the debtor will create a sufficient interest. Lastly, the effect of the PPSAs on the derivation principle is examined and the resulting limitations are discussed.

The author concludes that in spite of some uncertainty, the legislation achieves the laudable goal of creating as many individual interests as possible in the same personal property, thereby generating wealth for the maximum number of people.
Au Canada, la législation sur les sûretés relatives aux biens personnels (PPSA) permet à diverses personnes d'avoir des droits sur certains biens sans toutefois en être propriétaires. De ce fait, elle va à l'encontre du principe traditionnel qui relie strictement droits et propriété. Dans le présent article, l'auteur explore les droits établis par la législation, plus particulièrement en ce qui touche le débiteur. Un des problèmes vient du fait que la législation a tendance à utiliser indifféremment les termes "intérêt" et "droit" en ce qui concerne le débiteur d̀ certains égards, et d̀ établir une distinction dans d'autres cas. L'auteur étudie soigneusement la distinction entre ces termes et suggère que le premier serait le plus approprié.

L'auteur examine aussi les facteurs qui doivent être présents pour que le débiteur ait un intérêt suffisant sur le bien personnel en question. Ici, les données proviennent surtout $d u$ droit jurisprudentiel, la loi elle-même manquant de précision. Il existe donc une incertitude au sujet des facteurs qui créent un intérêt suffisant pour le débiteur, surtout quand il s'agit de déterminer si les certificats de titre, les contingents ou licences de production détenues par le débiteur créent un intérêt suffisant. Enfin, l'effet de la PPSA sur le principe de dérivation est examiné et les restrictions qui en découlent sont discutées.

L'auteur conclut que, malgré quelques incertitudes, la loi atteint l'objectif louable d'engendrer le plus d'intérèts individuels possibles sur les mêmes biens personnels, ce qui crée des richesses pour un nombre maximal de personnes.

\section{TABLE OF CONTENTS}

I. INTRODUCTION $\ldots \ldots \ldots \ldots \ldots \ldots \ldots \ldots \ldots \ldots \ldots \ldots$

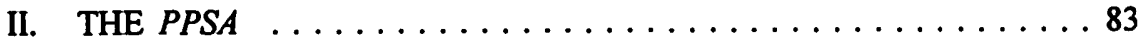

III. POINTS OF DEFINITION AND USAGE $\ldots \ldots \ldots \ldots \ldots \ldots 86$

IV. WHAT CONSTITUTES A

SUFFICIENT INTEREST? $\ldots \ldots \ldots \ldots \ldots \ldots \ldots \ldots \ldots \ldots$

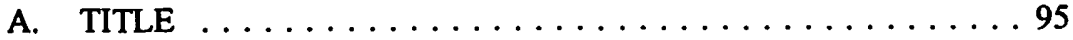

B. VOIDABLE TITLE $\ldots \ldots \ldots \ldots \ldots \ldots \ldots \ldots \ldots \ldots$

C. MERE POSSESSION $\ldots \ldots \ldots \ldots \ldots \ldots \ldots \ldots \ldots$

Faculty of Law, U.B.C. The author wishes to thank Robert Hayhoe, Vancouver, and Geoff Ho, Edmonton, for their comments on earlier drafts of this article. 
D. CERTIFICATE OF TITLE . . . . . . . . . . . . 102

E. PRODUCTION QUOTA OR LICENCE . . . . . . . . . 104

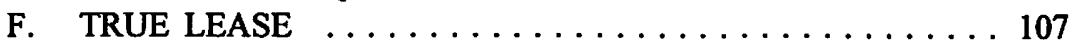

G. FUTURE PROPERTY . . . . . . . . . . . . . . . . . 109

V. THE DEPENDENCY OF INTERESTS: THE DERIVATION PRINCIPLE AND ITS EXCEPTIONS . . . . . 110

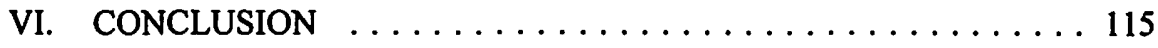

\section{INTRODUCTION}

In an simplistic world, though probably not in Utopia, there would be no secured transactions because there would be no splitting of interests in personal property. Interest would be based on possession. What one did not possess one would have no interest in and therefore no power over. With possession would come power and entitlement. This system, however, would make transfer and accumulation of wealth (to the extent that wealth is based on personal property) a burdensome and even brutal affair as it could only be accomplished by amassing actual control of movables. Thus the law devised the idea that one could have rights to or power over (that is, an interest in) personal property even though one did not actually possess it. ${ }^{1}$ It accepted the idea that there could be different sorts of rights or power in relation to the same item of personal property, that is, there could be different interests in the same item. Dominion need not reside in just one person. This conceptual division of interest and possession and the fracturing of an interest ${ }^{2}$ facilitates commerce and makes our law of secured transactions possible. ${ }^{3}$

It should not be forgotten, however, that the common law regards much of this development as an exception to the equation of possession and power. Possession is nine-tenths of the law. Any exception to that must be based on a good reason. Twyne's $\mathrm{Case}^{4}$ stands for the view that separation of ownership and possession should be viewed with caution. In that case, a debtor made a secret assignment of all his goods and chattels to one of his creditors so that another could not avail himself of them in that creditor's suit of debt. The Court held that the conveyance was fraudulent and set it aside. The Court paid particular attention to the fact that the debtor remained in possession of the goods and chattels.

In terms of establishing an interest, the common law perceived possession to be the best standard to judge a claim. Thus there are cases that give a prima facie interest in

1

For an historical treatment of this issue in the common law, see Sir W.S. Holdsworth, A History of English Law, v. VII, 2d ed. (London: Methuen, 1937) at 447-515. Important cases in related areas include Holroyd v. Marshall (1862), 11 E.R. 999; and Tailby v. Official Receiver (1888), 13 A.C. 523.

2 Possession can be split as well into actual and symbolic.

3 See generally D.G. Baird \& T.H. Jackson, "Possession and Ownership: An Examination of the Scope of Article 9" (1983) 35 Stan. L. Rev. 175; E.L. Tyler \& N.E. Palmer, Crossley Vaines' Personal Property, 5th ed. (London: Butterworths, 1973); D.W. McLauchlan, "Securities over Future Goods" (1973-75) 7 Vic. U. Well. L. Rev. 122 and 237. 
personal property to whoever possesses it. In Bird v. Fort Frances, a young boy, while playing at the rear of a building on private property, found a can on a sill forming part of the understructure of the building. The can contained a large sum of money which he handed to his mother, who hid it. The police found out and came and asked for the money in order to return it to its "owner". The owner was never found and the money was turned over to the municipality. The boy sued to recover the money and the Court held that he was entitled to succeed. McRuer C.J.H.C. said:

[I]t is not necessary for me to decide whether the taking was with felonious intent or not, as I think in this case the same result flows. In my view the authorities with which I have dealt justify the conclusion that where $A$ enters upon the land of $B$ and takes possession of and removes chattels to which $B$ asserts no legal right, and $A$ is wrongfully dispossessed of those chattels, he may bring an action to recover the same. ${ }^{5}$

Even in the Personal Property Security Act (PPSA), ${ }^{6}$ possession is important for establishing an interest in personal property. If a secured party has possession of collateral, he need not register his interest anywhere. ${ }^{7}$ Possession is sufficient notice to the world. It would defeat the interests of most debtors in seeking credit if they had to depart with their personal property in order to receive a loan. The point of the loan is to allow the debtor to use her personal property to better advantage or to acquire more. Thus secured parties are given the ability to have an interest in (that is, specified powers over) personal property which they do not possess, to ensure that they are repaid by the debtor. This separation of possession and power gives rise to the question of what personal property the secured party has an interest in. The PPSA answers this problem by demanding that a secured party's interest in personal property attach. One of the requirements of attachment is that the debtor have "rights in the collateral". ${ }^{8}$ The secured party's interest depends on the debtor's interest.

What the PPSA does not tell us is what is meant by the debtor's having "rights" in, or an "interest" in, personal property. This article examines this topic and related issues." It first examines how the issues arise in the context of the PPSA and then

Bird v. Fort Frances, [1949] 2 D.L.R. 791 (Ont. H.C.) at 799; see also Armory v. Delamirie (1772), 93 E.R. 664.

6 The PPSAs in force on 1 May 1994 are as follows: Alberta, Personal Property Security Act, S.A. 1988, c. P-4.05; British Columbia, Personal Property Security Act, S.B.C. 1989, c. 36; Manitoba, Personal Property Security Act, R.S.M. 1987, c. P35; Ontario, Personal Property Security Act, R.S.O. 1990, c. P.10; Saskatchewan, Personal Property Security Act, S.S. 1979-80, c. P-6.1; Yukon, Personal Property Security Act, R.S.Y. 1986, c. 130. Manitoba, New Brunswick and Saskatchewan have plans to proclaim into effect in the near future PPSAs similar to Alberta and B.C. The Northwest Territories' PPSA will be proclaimed in the more distant future. P.E.I. has passed a PPSA (Personal Property Security Act, S.P.E.I. 1990, c. 42), but has no plans to proclaim it. References in this paper will be to sections already in force.

Alta., s. 12(1)(b); B.C., s. 12(1)(b); Man., s. 12(1)(c); Ont., s. 11(2)(c); Sask., s. 12(1)(b); Yukon, s. $11(1)(b)$.

$9 \quad$ Other relevant articles include R.J. Wood \& M.I. Wylie, "Non-Consensual Security Interests in Personal Property" (1992) 30 Alta. L. Rev. 1055; R.C. Cuming, "True Leases and Security Leases under Canadian Personal Property Security Acts" (1982-83) 7 Can. Bus. L.J. 251; R.C. Clark, 
proceeds to look at some important issues of terminology and definition. The article then treats the question of sufficiency of rights or interests in the PPSA context. The last section of the article deals with the extent to which it is necessary for such interests to be derived from other interests.

It will be concluded that there are difficulties in the language used in the PPSA. The phrase "rights in the collateral" is problematic and the interests of simplicity could be better served by referring to "an interest in personal property." On the issue of sufficiency of interest, the article concludes that, although there has been much litigation on this point, the issue has been misconstrued. The PPSA does not require that there be a "sufficient" interest, only that there be an interest. In some cases, the rule of nemo dat quod non habet, the derivation principle, will control the extent of the interest acquired by the secured party. In many cases, however, the PPSA will allow the secured party to acquire more than the debtor had to give.

\section{THE PPSA}

The question of what is a debtor's "interest", or what are a debtor's "rights", is important in the PPSA context because the operation of the whole statute, a statute about security interests, depends on its answer. Two sections, pivotal because they determine whether or not there is a security interest, make the question of "rights" essential to their operation. ${ }^{10}$ The attachment section makes the existence of "rights" imperative for the existence of any security interest." The definition of "purchase money security interest" in the definitions section ${ }^{12}$ makes the issue determinative of the existence of this special security interest.

The more important use of these is in the section dealing with the attachment (that is, the creation as between the secured party and the debtor) of security interests. A security interest, the section says, attaches when among other requirements, "the debtor has rights in the collateral." This section should say rights in "personal property" instead of "collateral". "Collateral" is defined as "personal property that is subject to a security interest."13 Because the attachment section deals with the steps involved in deciding whether there is a security interest, it is odd that one step refers to something ("collateral"), that exists only if there is already a security interest. This article will therefore refer to "personal property", except where "collateral" is the correct word to

"Abstract Rights versus Paper Rights under Article 9 of the Uniform Commercial Code" (1975) 84 Yale L.J. 445; R.A. Lord, "Rights of Secured Creditors in Returned and Repossessed Goods under the Uniform Commercial Code: A Study of Section 9-306(5)" (1976-77) 15 Duq. L. Rev. 165; P.H. Shur, "Reclaiming Possession of Leased or Sold Goods" (1993) 26 U.C.C.L.J. 111. The issue is much more important under the PPSA than it was under the legislation it replaced. In the earlier legislation, although there is reference to "interests" and "rights", the whole legislative schemes were not dependent on those terms. For some references to those terms in earlier legislation, see, for example, Book Accounts Assignment Act, R.S.B.C. 1979, c. 32, s. 11(2); Chattel Mortgage Act, R.S.B.C. 1979, c. 48, s. 1(1) (c) "chattel mortgage" and (f) "chattels". Supra note 8.

Alta., s. 1(1)(ii); B.C., s. 1(1); Man., s. 1; Ont., s. 1(1); Sask., s. 2(gg); Yukon, s. 1(1).

Alta., s. 1(1)(f); B.C., s. 1(1); Man., s. 1; Ont., s. 1(1); Sask., s. 2(f); Yukon, s. 1(1). 
use. By specifically dealing with certain situations, the attachment section attempts to help with the question of deciding when rights exist. Thus, s. 12(3) of the Alberta PPSA says that the debtor has no rights in crops until they become growing crops, the young of animals until they are conceived, minerals until they are extracted, or trees other than crops until they are severed. ${ }^{14}$ This approach is modelled on s. 9-204 of the 1962 Uniform Commercial Code (UCC), ${ }^{15}$ an approach which was abandoned in the 1972 UCC. ${ }^{16}$ While the use of such examples to deal with problems is obviously of some use in resolving the issue of the existence of an interest, they are at best peripheral situations.

The attachment sections in the Western PPSAs go further in their treatment of specific situations than does the Ontario PPSA, and indicate that the debtor obtains rights in goods leased or consigned when she obtains possession of them. ${ }^{17}$ Evidently this was thought necessary, because these PPSAs also include in the definition of "security interest" an interest in goods leased for a term of more than one year and an interest in goods supplied pursuant to a commercial consignment. ${ }^{18}$ The drafters' fear must have been that absent such a provision specifically deeming the lessee or the consignee to have an interest in the leased or consigned personal property, the inclusion of leases for a term of more than one year, or commercial consignments as security interests, might have been for naught if a court decided that such a security interest could never attach because the lessee or assignee had no interest in such personal property. However, as will be argued, a lessee or consignee does have an interest in such personal property and therefore, a deeming provision was not really necessary.

Although the attachment section is vital in introducing the idea of rights in collateral (or personal property) into the PPSA, and although it does give some examples, it still does not answer at all the basic question of what a right or interest is. As this question is critical for the operation of the rest of the PPSA, it is left largely for the courts to determine what it might mean. ${ }^{19}$

"Rights in the collateral" is also central to the idea of a purchase money security interest (PMSI). A PMSI is defined in part as a security interest in collateral (a) to secure payment of all or part of its purchase price, and (b) by a person who gives value

See B.C., s. 12(3); Man., s. 12(2); Ont., s. 11(3); Sask., s. 12(3); Yukon, s. 11(3). These provisions vary slightly from jurisdiction to jurisdiction.

The American Law Institute National Conference of Commissioners on Uniform State Laws, Uniform Commercial Code: 1962 Official Text with Comments (Philadelphia: American Law Institute, 1963).

The American Law Institute National Conference of Commissioners on Uniform State Laws, Uniform Commercial Code: 1972 Official Text with Comments and Appendix (Philadelphia: American Law Institute, 1973). The attachment section is now s. 9-203.

Alta., s. 12(2); B.C., s. 12(2); Sask., s. 12(2)(b); Yukon, s. 11(2).

Alta., s. 1(1)(qq)(ii) (B) and (C); B.C., s. 1(1); Sask., s. 2(nn) (ii) and (iii); Yukon, s. 1(1).

There is a similar quandary in real property as to what is meant by an "interest in land". The law in this area does not deal so much with what is meant by "interest" as with what is meant by an "interest in land". See, for example, Canadian Bank of Commerce v. Yorkshire \& Canadian Trust Ltd., [1939] 1 D.L.R. 401; Re Urman (1983), 3 P.P.S.A.C. 191 (Ont. C.A.); Royal Bank of Canada v. Kleemola (1991), 2 P.P.S.A.C. (2d) 5 (Man. Q.B.). 
for the purpose of enabling the debtor to acquire rights in the collateral, to the extent that the value is applied to acquire the rights. ${ }^{20}$ What does it mean to help the debtor acquire rights in the collateral? It is not the collateral which has to be acquired by the assistance of the secured party but rather rights in the collateral. Therefore, it appears that there can be a PMSI even where the debtor had already acquired the collateral, so long as the secured party allowed the debtor to expand her "rights" in the collateral. The cases support this idea, though they do not squarely address the issue of what it means to have a right in the collateral.

The issue of the PMSI arose in Greyvest Leasing Inc. v. CIBC. There the question was whether a secured party could get a PMSI in collateral already in the possession of the debtor. Gotlib J. said:

\begin{abstract}
Because a debtor has some rights in an item of collateral does not mean that it cannot obtain further rights. By giving value to the debtor after the debtor has acquired rights in the collateral the creditor has not enabled the debtor to acquire those rights but the creditor may have enabled the debtor to acquire other subsequent rights in the collateral. Only when the debtor has acquired "all possible rights" in the collateral (North Platte State Bank v. Production Credit Association of North Platte, 200 N.W. $2 d 1$ (Neb. S. Crt., 1972) does it follow that a subsequent giving of value by the creditor could not have enabled the debtor to acquire rights in the collateral. ${ }^{21}$
\end{abstract}

This raises the question of what it means to have "all possible rights", a question which the Court never completely answers. Merely paying money to help the debtor pay for its collateral was not sufficient:

If a creditor could obtain a P.M.S.I. merely by helping a debtor pay for something of which the debtor had already taken possession then all lenders to debtors who had not fully paid for all property in their possession could obtain P.M.S.I.'s and take priority over earlier general creditors. That cannot have been the Legislature's intention. ${ }^{22}$

In fact, the Court said that in some such situations the debtor could be said to have fewer rights after giving the security interest. Beyond this, the decision is of little assistance.

A somewhat different approach, and one called more "in tune with commercial realities, ${ }^{123}$ was taken in Agricultural Credit Corp. of Saskatchewan v. Pettyjohn. In that case, loans were used to buy cattle. However, the loan from ACCS was actually made after the cattle had already been bought. The Court did not see this as an obstacle to ACCS's having a PMSI. Sherstobitoff J.A. said:

Alta., s. 1(1)(ii); B.C., s. 1(1); Man., s. 1; Ont., s. 1(1); Sask., s. 2(gg); Yukon, s. 1(1). The wording varies from jurisdiction to jurisdiction.

(1991), 1 P.P.S.A.C. (2d) 264 (Ont. Gen. Div.) at 269 [hereinafter Greyvest Leasing].

lbid.

M.W. Milani, "Creation, Maintenance and Tracing of Purchase-Money Security Interests: ACS v. Pettyjohn; Battlefords Credit Union Limited v. Ilnicki" (1991-92) 7 B.F.L.R. 463 at 466. 


\begin{abstract}
How can it be said that the monies advanced were used to acquire rights when the purchase had already taken place and the rights already acquired? It is, however, commercially unreasonable to divide the transactions so minutely. The Pettyjohns used the value given to them to pay off interim financing, but the interim financing had not been obtained as a separate transaction, but always with the view that it would be repaid through the monies advanced by A.C.C.S. The Pettyjohns used the value given as part of a larger, commercially reasonable transaction to acquire rights in the 1981 and 1984 cattle. The fact that the use of the value given was, due to the nature of the transaction, after the acquisition of the rights does not alter the conclusion that the value given was used to acquire those rights. $^{24}$
\end{abstract}

This decision, though probably more practical in its result, still does not add a great deal to our knowledge of what it means to have rights. What a PMSI must mean in this regard is that the secured party's actions permit the debtor to have a power in relation to the collateral that the debtor did not have before the secured party's actions. A secured party's loan might allow the debtor to convert her interest in personal property from that of, say, a lessor to that of a purchaser. Thus there is the acquisition of a greater (or at least a different) interest (or "rights" in the language of the PPSA) in the personal property. If the debtor were already a purchaser of the personal property and the secured party's loan merely enabled the debtor to help pay off her debt to another person, then the secured party's interest in the personal property should not be seen as a PMSI, because the secured party's loan has not (necessarily) enabled the debtor to acquire any new power in relation to the personal property that she did not already have. Greyvest Leasing and Pettyjohn should not be seen as inconsistent. The Court in Pettyjohn simply said that to determine whether a secured party has enabled the debtor to "acquire rights in the collateral", one should not take too technical an approach or be too obsessed with the precise order of events. Regard for the general picture is more reasonable. The decision in Greyvest Leasing does not contradict this approach.

\title{
III. POINTS OF DEFINITION AND USAGE
}

One of the more unsatisfying aspects of the PPSA is the way in which it appears at times to treat a "right" and an "interest" as the same thing, while at other times the usage can be construed to draw a distinction. Despite the arguments that can be made to the contrary based on the provisions of the PPSA, some of which will be examined in the paragraphs below, "rights" and "interests" are best treated as equivalents in the PPSA context, in so far as they are used in the sense of a legal entitlement of some sort to personal property.

Canada has very little jurisprudence that helps with the question of what constitutes a right or interest in the PPSA context. One case that gives the matter some consideration is International Harvester Credit Corp. of Canada Ltd. v. Bell's Dairy Ltd. This case is support for a very general approach to the word "interest". Here the 
Saskatchewan Court of Appeal dealt with what is meant by the "interest" of a trustee in bankruptcy in s. $20 .{ }^{25}$ Cameron J.A. said:

To begin with, the section is concerned with competing "interests", a word referred to in Black's Law Dictionary, 5th ed. (1979), as:

The most general term that can be employed to denote a right, claim, or legal share in something.

The Shorter Oxford English Dictionary defines the term, "interest" in its legal sense, to include:

The relation of being objectively concerned in something, by having a right or title to, a claim upon, or a share in [the thing].

In the context in which we are dealing the term [sic] I would take its ordinary meaning to be that found in the Oxford English Dictionary (See "The Quickening Pace of Jurisprudence Under The Ontario Personal Property Security Act" (1979-80), 4 Can. Bus. L.J. 54 by Professor Jacob Ziegel and in particular that portion of the article appearing at 66-69 under the head "Relationship with the Bankruptcy Act". It contains a helpful discussion of the way in which the word "interest" might be construed in the context of the subordination of one interest to another, concluding that whatever one may say of the term it "is an elastic concept which should not be analyzed with Aristotelian exactness" [p. 60].).

Now having regard especially for the frequency with which the statute cuts through traditional concepts and emphasizes substance over form, I see no valid reason, in construing s. 20(1)(b), (c) and (d), to depart from the ordinary meaning of the word "interest". Nor do I see any good reason for classifying the interests referred to in the section as "proprietary" or "possessory", or "specific" or "general", or "contingent" or what have you, and then attributing to one class a higher value than another. ${ }^{26}$

The definition sections of the PPSAs contain no definitions of "rights" or "interest", except to the extent that "security interest" is given a definition. However even there, the definition deals only with the word "security" and does not define at all the "interest" part of the term. The word "interest" is simply repeated.

The PPSA uses both the terms "rights" and "interest" without there being a clear idea of why two terms are used. What is the difference between an interest and a right? Are they used just for the sake of variety? One of the important aspects of legislative drafting is of course the idea that different words used in a statute mean different things. ${ }^{27}$ Some examples of this perplexing situation in the PPSA follow. 
In the B.C. definitions section "debtor" is defined to mean "(a) a person who owes payment or performance of an obligation secured, whether or not that person owns or has rights in the collateral." ${ }^{.28}$ The definition appears to distinguish "rights" from ownership; it does not say "or otherwise has rights." If anything constitutes having rights, however, it must be ownership. The definition of debtor goes on in subsequent paragraphs to refer to "the interest of a person referred to in paragraph (a)." ${ }^{29}$ So, the idea of an interest appears to be more generalized. It embodies ownership or rights but, as the definitions cited in Bell's Dairy Ltd. indicate, it might even go beyond these terms.

Excluded from the PPSA is "a lien, charge or other interest given by a rule of law or by an enactment....." ${ }^{130}$ We can take from this definition that an interest includes a lien or charge. There can be an "interest" in a "right" according to the same section which allows for an "interest" in a "right to payment". ${ }^{31}$ In this case then, the conclusion might be drawn that a right is a larger thing than an interest, since there can be an interest in a right, apparently not exhausting or consuming the right.

Section 20 deals with the subordination of unperfected security interests. ${ }^{32}$ The Alberta provision lists various individuals who acquire "interests", such as a person who causes collateral to be seized under legal process or who obtains a charging order or equitable execution affecting or relating to the collateral (Alberta s. 20(1)(a)(i)), ${ }^{33}$ and a sheriff who has seized or has a right to the collateral under the Execution Creditors Act (s. 20(1)(a)(ii)). ${ }^{34}$ Here again we see the use of the term "interest" as something which exists within a right, or by virtue of a right. Section 20(1)(a)(iv) includes as an interest that which a representative of creditors has, "but only for the purposes of enforcing the rights of a person referred to in subclause (i). ${ }^{135}$ Therefore, it appears that seizing collateral under a legal process, or obtaining a charging order or equitable execution (that is, the things mentioned in subclause (i)) are rights as well as interests. Here, we see an equivalency in the terms.

Section 30 of the Alberta and B.C. PPSAs is another section that uses both terms, interest and rights, again apparently as interchangeable concepts. This provision speaks of a "buyer of goods" as a person who obtains "vested rights" in goods by virtue of those goods becoming a fixture or accession to property in which that person "has an interest. ${ }^{\text {"16 }}$ The meanings of "rights" and "interests" in property in this context appear to be indistinguishable.

B.C., s. 1(1). See Alta., s. 1(1)(1); Man., s. 1; Ont., s. 1(1); Sask., s. 2(k); Yukon, s. 1(1).

B.C., s. $1(1)$. The other jurisdictions speak in the same section of a "debtor's interest in collateral": Alta., s. 1(1)(1)(iv); Man., s. 1; Ont., s. 1(1); Sask., s. 2(k); Yukon, s. 1(1).

Alta., s. 4(a); B.C., s. 4(a); Sask., s. 4(a); Yukon, s. 3(a).

Alta., s. 4(e) and (g); B.C., s. 4(e) and (g); Sask., s. 4(f); Yukon, s. 3(h).

This is s. 20 in all jurisdictions except: Man., s. 22; and Yukon, s. 19.

B.C., s. 20(a)(i); Sask., s. 20(1)(b); Yukon, s. 19(1)(b).

B.C., s. 20(a)(ii) (under the Creditors Assistance Act); Sask., s. 20(1)(c) (under the Creditors' Relief $A c t$ ); Yukon, s. 19(1)(c) (under the Creditors Relief $A c t$ ).

B.C., s. 20(a)(iv); Sask., s. 20(1)(d); Yukon, s. 19(1)(d). See Man., s. 22(2); Ont., s. 20(2).

Alta., s. 30(1)(a); B.C., s. 30(1). The other jurisdictions do not (yet) have such a definition. 
Section 33, in most jurisdictions, deals with a transfer of a debtor's rights in collateral. ${ }^{37}$ It allows a debtor to transfer her "rights" in collateral. In s. 35 of the Western PPSAs, there is reference to a debtor transferring "an interest in collateral. ${ }^{138}$ The provision dealing with transfers of collateral by the debtor similarly refers to a "debtor's interest in the collateral." ${ }^{39}$ Can this be something different from what is meant in s. 33 ? One hardly thinks so.

Little can be drawn from this analysis except that "rights" and "interests" are used with imprecision. It would appear best to say that "rights" and "interest" are synonyms, but some sections of the PPSA obviously make this a somewhat difficult conclusion to draw. The less laden word is "interest", which is a general term including "rights". There is nothing "wrong" with the word "rights". It is simply more problematic in that it can be less clear what is meant by the word.

There is a massive literature on the issue of what is meant by the word "right". Arthur Corbin in his introduction to Hohfeld's book, Fundamental Legal Conceptions as Applied in Judicial Reasoning, ${ }^{40}$ notes how many concepts are lumped together "under the single, wonderful, all-inclusive term 'rights' - a term with 20 meanings." Hohfeld thought the word should be restricted to one meaning. He criticised the situation where "the term 'rights' tends to be used indiscriminately to cover what in a given case may be a privilege, a power, or an immunity, rather than a right in the strictest sense." ${ }^{12}$ Hohfeld thought that words like "right" could not be defined, so much as situated, in the context of their jural correlatives and jural opposites. According to his analysis, the jural correlative of a "right" is a "duty". They are the description of the two ends of a single relation. The jural opposite of a "right" is a "noright". This conception of what is meant by a right is remarkably similar to that of Austin, who said:

Every right supposes a duty incumbent on a party or parties other than the party entitled. Through the imposition of that corresponding duty, the right was conferred. Through the continuance of that corresponding duty, the right continues to exist. ${ }^{43}$

Distinct from a "right", according to Hohfeld, is a "power" whose correlative is a "liability" and whose opposite is a "disability". A close synonym for "power" is an "ability". Hohfeld gave examples of legal powers, among them the following:

Alta., s. 33(2); B.C., s. 33(2); Man., s. 33; Ont., s. 39; Sask., s. 33; Yukon, s. 32.

Alta., s. 35(7); B.C., s. 35(8), Sask., s. 35(6); Yukon, s. 34(6). The equivalents to s. 35 in other jurisdictions (Man., s. 35; Ont., s. 30) have no equivalent to this language.

Alta., s. 50; B.C., s. 51; Man., s. 50; Ont., s. 48; Sask., s. 49; Yukon, s. 45.

W.N. Hohfeld, Fundamental Legal Conceptions as Applied in Judicial Reasoning (New Haven:

Yale University Press, 1964).

Ibid. at viii.

Ibid. at 36.

J. Austin, The Province of Jurisprudence Determined \& The Uses of the Study of Jurisprudence (London: Weidenfeld and Nicolson, 1954) at 158. Austin expanded on the usage of the word

"right" at note 26 at $285-88$. 
Thus, X, the owner of ordinary personal property "in a tangible object" has the power to extinguish his own legal interest (rights, powers, immunities, etc.) through that totality of operative facts known as abandonment; and - simultaneously and correlatively - to create in other persons privileges and powers relating to the abandoned object, - e.g., the power to acquire title to the latter by appropriating it. Similarly, $\mathrm{X}$ has the power to transfer his interest to $\mathrm{Y}, \mathrm{-}$ that is, to extinguish his own interest and concomitantly create in $\mathrm{Y}$ a new and corresponding interest. ${ }^{44}$

It is significant that the terms "powers" and "rights" are grouped together under the larger concept "legal interest".

Hohfeld's discussion and distinctions have provoked a great deal of comment. They are generally accepted as a useful starting point. ${ }^{45}$ Often different terms are suggested than those advocated by Hohfeld. Geoffrey Marshall, for example, prefers the word "entitlement" to the word "power". ${ }^{46}$ Some reject Hohfeld's analysis as less than useful. ${ }^{47}$ As analyzed by H.L.A. Hart, Bentham made the same distinction in meaning in the word "right" that corresponds with Hohfeld's "right" and "power", although Bentham retained the same word for both meanings. He differentiated a right a person has which results from the absence of legal obligation ${ }^{48}$ from a right which results from an obligation imposed on another by law. ${ }^{49}$ This second situation is what Hohfeld would describe as a "right".

In the context of the PPSA and attachment, when the words "rights" and "interest" are used what can be meant is that the holder of the right or interest has the ability to do something in relation to the personal property concerned. What is meant, therefore, is a situation where a person has an ability in relation to the personal property which will entail a legal liability on others. In Hohfeldian terms, this is a "power" not a "right". ${ }^{51}$ On the other hand, sometimes what is intended is a Hohfeldian "right" which entails a correlative "duty" on another. Often both a "right" and a "power" are involved. Thus, when a person's interest is that of a lessee in an open-ended lease, he has the right to use the goods for an agreed period (and the lessor has the duty to allow the lessee such use). The lessee also has the power to end the lease (and the lessor is liable to this exercise of power).

Supra note $\mathbf{4 0}$ at 51 .

See C.F.H. Tapper, "Powers and Secondary Rules of Change" in A.W.B. Simpson, ed., Oxford Essays in Jurisprudence (Second Series) (Oxford: Clarendon Press, 1973) 242; and G. Marshall, "Rights, Options, and Entitlements" in Simpson ed., ibid. 228.

Ibid.

For example, see A.M. Honore, "Rights of Exclusion and Immunities against Divesting" (1960) 34 Tulane Law Rev. 453. See also A.M. Honore,, "Ownership" in A.G. Guest, ed., Oxford Essays in Jurisprudence (First Series) (Oxford: Oxford University Press, 1961) 107.

J. Bentham, An Introduction to the Principles of Morals and Legislation, ed. by J.H. Burns \& H.L.A. Hart eds., (London: Athlone Press, 1970) at c. XVI, para. 26.

J. Bentham, Of Laws in General, H.L.A. Hart, ed. (London: Athlone Press, 1970) at 57-8.

On Bentham's uses and an analysis in relation to Hohfeld see H.L.A. Hart, "Bentham on Legal Rights" in Simpson, ed., supra note 45; H.L.A. Hart, Essays on Bentham: Jurisprudence and Political Theory, (Oxford: Clarendon Press, 1982) at c. VII and VIII.

See R.L. Jordan \& W.D. Warren, Commercial Law, 3d ed., Commentary (Westbury, New York: Foundation Press, 1992) at 16. 
It is not suggested here that the word "power(s)" replace or be added to "right(s)" where the latter is used in this context in the PPSA. Both words are controversial and neither conveys a simple, straightforward meaning. Both introduce complexities into a statutory regime that aims for simplicity. What is suggested is that the word "interest" would be preferable. It is a more general term that, even according to Hohfeld, comprehends both rights and powers. Its use sidesteps the argument over what precisely is a "right" (as opposed to, say, a "power"). As discussed, the Saskatchewan Court of Appeal has already sanctioned a generalized definition for "interest". ${ }^{52}$ As also discussed, the PPSA mixes the words "rights" and "interest" without appearing to intend any real difference in the terms. The use of two words can only complicate what is not meant to be complicated. Linguistic variety is not the purpose of the PPSA; simplification is. ${ }^{53}$ "Interest" is the preferable word and should supplant "rights" when that word is used in the context of a phrase like "rights. in the collateral."

While there may be no important difference between "rights" and an "interest" in the PPSA context, one distinction that must be drawn is between an interest in personal property and the rank of that interest. The PPSA deals well with the latter concept and is essentially occupied with that question in the first parts of the Act. One can speak of a greater interest and a lesser interest in the context of the extent or size of the interest. Thus a lessor can be said to have a bigger interest than a lessee. The lessee's interest is carved out of the lessor's interest. Similarly, a secured party can have an interest carved out of the debtor/owner's interest in the personal property and one could say that the debtor/owner, therefore, has a greater or more fundamental interest. However, this tells us nothing about the priority of those interests. A person with a smaller interest can demand to have that interest satisfied first. ${ }^{54}$ Rules about priority can affect the enjoyment of an interest in personal property, if, as is the case in the $P P S A$, the priority accorded to one party can eliminate the interest of another. In the PPSA for example, where a secured party with priority to collateral seizes and disposes of the collateral, that secured party's actions eliminate the interests of the debtor and of parties subordinate to the debtor and the disposing secured party. ${ }^{55}$ These issues of priority must always be kept in mind, but because they are primarily about secured party's interests, they are not central to this article.

\section{WHAT CONSTITUTES A SUFFICIENT INTEREST?}

A debtor's interest in personal property can be created through a number of different means. The appropriate means will depend on the type of interest involved. For a mere right to possess, delivery will suffice. For the right to own or claim title, resort to sales

$32 \quad$ See Bell's Dairy Lıd., supra note 26.

53 The PPSA is primarily about security interests in personal property. There is no reason why the drafters could not have said a "security right" in personal property, if only for variety. On liens that attach at the same time, see D.G. Carlson, "Simultaneous Attachment of Liens on After-Acquired Property" (1985) 6 Cardozo L. Rev. 505. 
law will be necessary to ascertain whether property has passed. ${ }^{56}$ Where there is a sale of unascertained goods, ascertainment or appropriation of goods will be essential to the debtor's acquiring an interest. It is not always clear when exactly this happens. In Manning v. Furnasman Heating Ltd. ${ }^{57}$ the question arose of when it could be said that a builder got an interest in heating equipment provided by a person who was to supply and install the heating equipment. The Court held that until the supplier actually took the equipment to the house and installed it, the builder did not have an interest in the goods which would be sufficient for the security interests of its creditors to attach to the equipment. According to Scollin J.:

It was only when Furnasman [the supplier] installed the specific equipment referred to later in the financing statement that the builder got any rights to that equipment and it was only then that the builder became obligated to pay Furnasman for what Furnasman itself in its billing called the "complete" contract. $^{58}$

However it is created, an interest in personal property is a relationship between an individual and a thing. ${ }^{59}$ What sort of relationships are sufficient? Courts have spent some time and energy determining what constitutes a sufficient interest in order for a security interest to attach. This section examines some of the situations that have been the subject of judicial consideration.

The PPSA, however, does not speak in the attachment section about a debtor having "sufficient" rights; it only requires that a debtor have "rights" in order for a security interest to attach. It appears that the issue of what constitutes a security interest is sometimes conflated with the issue of what constitutes "rights" or an "interest" ${ }^{60}$ While

See the Sale of Goods Acts in the PPSA jurisdictions: R.S.A. 1980, c. S-2, ss. 20 and 21; R.S.B.C. 1979, c. 370, ss. 22 and 23; R.S.M. 1987, c. S10, ss. 19 and 20; R.S.O. 1990, c. S.1, ss. 18 and 19; R.S.S. 1978, c. S-1, ss. 19 and 20; R.S.Y. 1986, c. 154, ss. 18 and 19. (1985), 4 P.P.S.A.C. 246 (Man. Q.B.), affd (1985), 5 P.P.S.A.C. 67 (Man C.A.).

lbid. at 252. This issue was important because of the fixtures section of the PPSA which gave preferential treatment to secured parties (over those with interests in the land) when the security interest attaches before the goods become fixtures. According to this judgment, the security interest could not attach until the goods became fixtures because it was only then that the debtor had any interest in the goods.

On this point, R.M. Goode reminds us that a security interest creates real rights in an asset as opposed to personal rights to an asset. This is important because in principle the secured creditor will be entitled to remove the asset from the general body of creditors: R.M. Goode, Legal Problems of Credit and Security, 2d ed. (London: Sweet \& Maxwell, 1988) at 3-4. Attachment will give the creditor rights in rem against the debtor and a further step (perfection) is necessary to give the rights in rem against third parties. So until perfection a secured party has a right in rem against only the debtor about which R.M. Goode says "there is admittedly something odd": ibid. at 27 . He continues: "The fact is that a real right enforceable only against the debtor is scarcely distinguishable in its effects from a mere personal right.": ibid.

R. McLaren adopts the view that there must be "sufficient" rights:

The Act does not specify the quantum of "rights" which a debtor must have in the collateral to support a security interest. The case law conceming this requirement under the prior Act and the U.C.C. indicates that the debtor must have something more than mere possession, but less than full legal ownership, to satisfy the rights in the collateral requirement.

R.H. McLaren, Secured Transactions in Personal Property in Canada, 2d ed. (Toronto: Carswell, 1992) at 2-5. 
a lease or a consignment, for instance, might not constitute a security interest held by the lessor or the consignor, ${ }^{61}$ there is no reason to suppose that they do not create an interest in the lessee or the consignee. The fear appears to be that allowing the debtor an interest in these situations will entitle the secured party to take something from the lessor or the consignor which that person has not consented to. As will be explained, in the Western PPSAs, this is precisely what the statute intends. Elsewhere, the derivation principle should alleviate those concerns.

Even "mere possession" can be sufficient to give the debtor an interest in the personal property for the purposes of the definition of attachment and the definition of PMSI in the PPSA. The debtor must at least have the right to possess, ${ }^{62}$ otherwise the debtor's possession would be unlawful. This right to possession is an interest of the debtor in the personal property. The interest the debtor has in such a situation is minimal and very tenuous, but this is no reason why it is not enough to satisfy the PPSA. It is true that the interest the debtor has may be so negligible that it is of little or no value to the secured party, but this is as a result of the application of the principle nemo dat quod non habet, not because there are no "rights" as required by the attachment section.

A generous approach was taken in this regard in Kinetics Technology Int'l Corp. v. Fourth National Bank of Tulsa.$^{63}$ In that case, KTI was a company that designed and supplied process furnaces for the refinery and petrochemical industry. It entered into a contract with OHT whereby OHT would build eight furnace economizers to KTI's specifications, in part from materials supplied by $\mathrm{KTI}$ and in part from materials supplied by OHT. The purchase order form, used for the transfer of the materials from KTI to OHT, provided that title to goods delivered to OHT by KTI would remain in KTI.

Cuming and Wood take a more liberal approach and say: "Any legal or equitable proprietary interest qualifies as 'rights in the collateral'.": R.C. Cuming \& R.J. Wood, Alberta Personal Property Security Act Handbook, 2d ed. (Toronto: Carswell, 1993) at 114 (see, generally, 114-17); R.C. Cuming \& R.J. Wood, British Columbia Personal Property Security Act Handbook, 2d ed. (Toronto: Carswell, 1993) at 115 (see, generally, 115-18).

Even this distinction might not be supportable. It was advocated by Morris Shanker that leases in many instances should be in the PPSA, especially where the lease was for the bulk of the useful life of the leased goods: M.G. Shanker, "The Past, Present and Future of True Leases and Disguised Security Agreements: An Old Problem in Modem Apparel" (1982-83) 7 Can. Bus. L.J. 288. "The basic point is that lease transfers are essentially ownership transfers for a limited period of time...": ibid. at 304. It is equivalent to, say, selling an undivided half interest in a piece of equipment and retaining title to secure the purchase price. This is clearly a conditional sale transaction and Shanker says the same consequences for that should flow if instead is sold the absolute right to use the product for half its useful life - on lease. A lease simply "divides the ownership of the chattel on a temporal basis...": ibid. at 305. The Western PPSAs adopt this approach to a limited extent by including a lease for a term of more than one year in the PPSAs, for some purposes: Alta., s. 1(1)(qq)(ii)(c); B.C., s. 1(1); Sask., s. 2(nn)(iii); Yukon, s. 1(1). And the power to terminate possession.

6) 705 F. 2d 396 (10th Cir. 1983) [hereinafter Kinetics Technology]. This case deals with the "financing buyer" on which see T.J. Jackson \& A.T. Kronman, "A Plea for the Financing Buyer" (1975) 85 Yale L.J. 1. 
OHT began work on this contract but its financial situation deteriorated and eventually the bank took possession and control of OHT's plant where the KTI goods were located. The bank did this in part because of its position as a secured party who had taken a security interest in "all inventory now or hereafter owned by the Debtor." The financial statement relating to this was filed before KTI came into the picture.

Now KTI demanded the surrender of the manufactured goods and the goods it sent to OHT. On this point the Court held that the bank prevailed as Seymour Circ. Ct. J. indicated:

[1]t is clear that for a security interest to attach, a debtor must have some degree of control or authority over collateral placed in the debtor's possession. ${ }^{64}$

Here there was sufficient control and any other result would be contrary to public policy in misleading third parties. One might question the decision on the basis that the security interest was taken in property "owned" by the debtor. OHT certainly had an interest in the collateral, though it did not "own" it. However, the decision is most important for the expansive view it takes of the concept of interests for the purposes of attachment. Even in situations where a person has been given "mere possession" of property, can it not be said that that person has "some degree of control or authority" over it?

This section of the article looks at the sort of situations that give rise or could give rise to a debtor's interest in personal property in the $P P S A$ context. ${ }^{65}$ It has already been noted that the PPSA tells us little about these situations. On the whole, Article 9 of the UCC is of no more help than the PPSAs in clarifying what constitutes an interest. It has been said that the term "rights in the collateral" in Article 9 is merely an invitation to look elsewhere. ${ }^{66}$ American case law however, provides a great deal of assistance in this regard. The law in this area is deeply indebted to cows, their farmers, and their financiers, as many of the cases involve such elements. ${ }^{67}$ It was in one of those cattle cases that we are reminded that the core question here is the nature of the interest of the debtor, not the secured party or the true owner. In Brown v. U.S., Porter C.J. said:

Ibid. at 399.

Where it is the secured party's interest that we are concerned about, the situation is more straightforward. We simply look to what the PPSA requires. The parties must intend that a security interest attach to particular collateral. Absent this intention, no rights can exist: Sperry Inc. $v$. CIBC (1982), 40 O.R. (2d) 54 (H.C.J.); and Jones v. Davidson Partners Lid. (1981), 1 P.P.S.A.C. 242 (Ont. H.C.J.).

See S.W. Sanford, "Debtor's Rights in Collateral as a Requirement for Attachment of a Security Interest under the Uniform Commercial Code" (1981) 26 S.D.L. Rev. 163 at 204.

Brown v. U.S., 622 F. Supp. 1047 (D.C.S.D. 1985), Fricke v. Valley Production Credit Ass'n, 721 S.W. 2d 747 (Mo. Ct. App. 1986); First National Bank of Elkhart County v. Smoker, 286 N.E. 2d 203 (Ind. Ct. App. 1972); Jordan v. Butler, 156 N.W. $2 d 778$ (Sup. Ct. Neb. 1968); Rohweder v. Aberdeen Production Credit Ass'n, 765 F. 2d 109 (8th Cir. 1985); Matter of Samuels \& Co. Inc., 526 F. 2d 1238 (5th Cir. 1976); Towe Farms, Inc. v. Central lowa Prod. Credit Ass'n, 528 F. Supp. 500 (D.C. lowa 1981) [hereinafter Towe Farms]. 
Even if a party retains ownership interest in a piece of collateral, a debtor who retains that collateral is still able to mislead potential creditors by exercising his "rights" of possession and control over the collateral. It is the outward appearance of a debtor's rights of ownership and control in the collateral that determines whether attachment of a security interest is effective and not the right of a party who may have title to the collateral. ${ }^{68}$

In general, according to U.S. cases so long as the debtor has even a "marginal" interest in the personal property, it is sufficient to allow a lien to attach. ${ }^{69}$

\section{A. TITLE}

The PPSA says that the Act applies to every transaction that in substance creates a security interest, without regard to the person who has title to the collateral. ${ }^{70}$ Security interests would be needlessly restricted if they depended on the narrow conceptions of title and ownership." Although such a restrictive regime is quite possible, indeed, the Bank $A c t^{72}$ establishes one, it is less efficient and useful to commerce.

The point that title is irrelevant has been made time and again by the courts. Typical of a conditional sale is the transfer of possession to a debtor/purchaser with a right to transfer of ownership/title in the future upon payment of an agreed sum. Such possession undoubtedly endows the debtor with an interest in the property concerned,

Brown v. U.S., ibid. at 1050.

Matter of Samuels \& Co. Inc., supra note 67 at 1243; and Borg-Warner Acceptance Corp. v. C.I.T. Corp., 679 S.W. 2d 140 (Tex. Ct. App. 1984).

Alta., s. 3(1)(a); B.C., s. 2(1)(a); Man., s. 2(a); Ont., s. 2(a); Sask., s. 3; Yukon, s. 2.

Note, on the difficulty of co-ordinating the different concepts of ownership and their relevance see J.S. Ziegel, "The Quickening Pace of Jurisprudence Under the Ontario Personal Property Security Act" (1979-80) 4 Can. Bus. L.J. 54 and R.C. Anzivino, "When Does a Debtor Have Rights In the Collateral under Article 9 of the Uniform Commercial Code?" (1977) 61 Marq. L. Rev. 23.

On the problems inherent in the concepts of "title" and "ownership", see F.H. Lawson \& B. Rudden, The Law of Property, 2d ed. (Oxford: Clarendon Press, 1982) at 41-51; I. Davis, Effective Retention of Title (London: Fourmat, 1991) at 2-4.

Rare for the PPSA, the section on disposition of collateral on default speaks of an "owner" of collateral in the context of persons to whom notice of disposition of seized collateral should be sent: Alta, s. 60(4)(a); B.C., s. 59(6)(a); Man., s. 62(2); Ont., s. 63(4)(b); Sask., s. 59(4)(a); Yukon, s. 57(4)(a).

The Bank Act makes ownership by the debtor the key to the bank/creditor getting rights in the collateral: Bank Act, S.C. 1991, c. 46, ss. 426(2)(b) and 427(2)(b).

In Kawai Canada Music Lid. v. Encore Music Lid., [1993] 6 W.W.R. 173 (Alta. C.A.), the Alberta Court of Appeal held that a bank with a Bank Act security takes no interest in property which the debtor has on conditional sale where the title remains with the vendor. The debtor has "nothing higher than a right of possession until it is paid the purchase price" (at 179, per Curiam). The Court rejected the argument that, as a conditional purchaser under a conditional sales agreement, the buyer acquires an equitable interest in the collateral sufficient to constitute itself "owner" for the purposes of [then] s. 178(2). See also Rogerson Lumber Co. Ltd. v. Four Seasons Chalet Lid. (1980), 1 P.P.S.A.C. 160 (Ont. C.A.). 
despite the fact that the debtor does not (yet) have title to the collateral. ${ }^{73}$ For example, in Euroclean Canada Inc. v. Forest Glade Investments Ltd. ${ }^{74}$ Fitzpatrick J. noted that although the PPSA does not specify what rights a debtor needs to support a security interest, title is irrelevant. Under the conditional sales agreement in this case, the debtor acquired the right to immediate possession of the equipment involved and the right to receive legal title upon payment of the full purchase price. The Court held that those rights were sufficient for the creditor's security interest to attach. The Court of Appeal agreed with McLaren's Secured Transactions in Personal Property in Canada, that "rights in collateral" is very broad and encompasses a good many interests beyond legal or equitable title to the collateral being offered as security. ${ }^{75}$

While it is true that the PPSA states that the Act applies to a large number of transactions without regard to form and without regard to "the person who has title to the collateral"76 that does not mean that title is irrelevant under the PPSA for all purposes. ${ }^{77}$ Title will be relevant to establish the nature of the debtor's interest and what sort of interest the debtor can pass on to third parties. ${ }^{78}$ Furthermore, if it can be established that the debtor does have title then the debtor certainly has an interest in the personal property. Additionally, it is important to remember that when the PPSA says that a security interest can be created "without regard to the person who has title to the collateral," it does not thereby strip that person of all rights title otherwise gives. The PPSA may modify those rights and, as will be seen in some circumstances, ${ }^{79}$ eliminate them, but there is no general abolition of those rights.

\section{B. VOIDABLE TITLE}

What if the debtor has only a voidable title to the personal property? ${ }^{80} \mathrm{~A}$ voidable title exists "when the owner of goods intended to pass title to them, but his intent was fraudulently induced." ${ }^{81}$ Here the debtor has a somewhat tenuous title, but can pass

73

It is irrelevant whether the debtor who possesses the property is making the proper payment or not, so as eventually to get title: See In Re County Green Ltd. Partnership, 438 F. Supp. 693 (D.C. Va. 1977) at 696. See also L.B. Smith, Inc. v. Foley, 341 F. Supp. 810 (D.C. N.Y. 1972). (1984), 4 P.P.S.A.C. 56 (Ont. H.C.J.), rev'd (1985), 4 P.P.S.A.C. 271, leave to appeal to S.C.C. dismissed June 3, 1985.

75 Ibid. at 271. The Court distinguished the case of Rogerson Lumber Co. v. Four Seasons Chalet Lid., supra note 72 on the basis that it dealt with the Bank Act and not the PPSA. The current citation for this principle is McLaren, supra note 60 at 2-6. See also Haibeck v. No. 40 Taurus Ventures Lid. (1991), 2 P.P.S.A.C. (2d) 171 (B.C.S.C.); Fricke v. Valley Production Credit Ass'n, supra note 67, reversed and remanded on a different matter, 778 S.W. $2 d 829$ (Mo. Ct. App. 1989); First National Bank of Elkhart County v. Smoker, supra note 67; Baker v. Equitable Leasing Corp., 271 S.E. 2d 596 (Sup. Ct. S.C. 1980).

76 Supra note 70.

See Re Key National Leasing (1990), 1 P.P.S.A.C. (2d) 147 (Ont. C.A.) at 148.

See H.M. Smith, "Title and the Right to Possession under the Uniform Commercial Code" (196869) 10 B.C. Indus. \& Comm. L. Rev. 39.

See section V., "The Dependency of Interests: The Derivation Principle and its Exceptions", below at 110 .

See Anzivino, supra note 71 at 32-35.

W.D. Warren, "Cutting Off Claims of Ownership under the Uniform Commercial Code" (1963)

30 U. Chi. L. Rev. 469 at 475. 
on a better title to a third party under the Sale of Goods Act, at least in some circumstances. ${ }^{82}$ A secured party is like a bona fide purchaser for value of the goods which are the subject of the voidable title. If a voidable title gives the debtor the ability to pass on a valid title to third parties, even in limited circumstances, then the debtor must have an interest in the personal property.

It has been held that a bona fide creditor can get a good interest in collateral to which the debtor has only a voidable title because the debtor paid for the collateral with a bad cheque. The creditor could be acting in a bona fide manner even if the creditor knew the debtor had not paid his vendors. ${ }^{83}$ The creditor does not lose when later the vendor wants the goods back. Dealing with this issue in Matter of Samuels \& Co. Inc., the U.S. Court of Appeals, Fifth Circuit, adopted the views of the dissent of Godbold Cir. Ct. J., from the Court below:

The majority find that even if attachment occurred, C.I.T.'s [the creditor's] interest would be defeated by Stowers' [the owner's] reclamation. The theory behind this argument is that the rights of the Article Nine secured party are at best coextensive with the rights of the debtor; if the debtor loses his rights, the security interest too is lost.

Upon nonpayment Samuels [the debtor] lost the right to retain or dispose of the property, but the Code recognizes that the breaching buyer had the power to encumber, despite nonpayment, so long as he retained possession.... In the instant case, this power arose as a result of Stowers' delivery, and it did not terminate while the goods remained in Samuels' hands. The whole point of Article Nine is the continuity of perfected security interests once they have properly attached, despite subsequent loss of control or possession of the collateral by the debtor.... Article Nine does not except an unpaid cash seller from this overall plan. ${ }^{84}$

Similarly, in Jordan v. Butler, ${ }^{85}$ the purchaser of cattle had a voidable title because the cheques paid were dishonoured. The Court held that, nonetheless, the purchaser had sufficient rights in the collateral to grant a good title to a good faith purchaser for value, and therefore the purchaser had power to grant a lending company a valid lien on the cattle for the loan of money. In situations dealing with voidable title, therefore, courts appear to have regard for sales law in determining whether a good title could be passed on to a third party buyer by the debtor. If it could, then the debtor has a sufficient interest to grant a security interest to a secured party.

It is important to remember that the relevant time for considering the debtor's interest in the property is the time of attachment of the security interest. Providing that the debtor's interest has not yet been avoided at this time, the true owner's subsequent effort to avoid the agreement with the debtor cannot affect the secured party's interest. The principle protecting secured parties in the context of the debtor's voidable title has been extended in at least one case. In Swets Motor Sales, Inc. v. Pruisner, it was held 
that a secured party could take a good interest in property even if the debtor got the property through "fraud punishable as larcenous under the criminal law." ${ }^{86}$ All depended on the good faith of the lender.

\section{MERE POSSESSION}

While possession is the key to interests in personal property at common law and to a certain extent in the PPSA, mere possession of personal property is not usually held to be sufficient for a debtor to be said to have an interest in that property. ${ }^{87}$ Cases of a true bailment, where there are no added rights to the bailee beyond possession, usually result in the bailee not having a sufficient interest to support the attachment of a security interest. ${ }^{88}$ Similar to bailments is the agency situation. If the holder of goods receives them simply as an agent for another, then the holder does not have a sufficient interest in the personal property for the purposes of the PPSA. Thus, it has been held that if cows are received by a person as an agent for another then that agent cannot give any security interest in the cattle. ${ }^{89}$

A common type of agency situation will be the true consignment. In Manger v. Davis, a diamond ring owner gave the ring to a gemologist to sell. The owner of the ring brought an action to recover possession of the ring from a business which had acquired the ring as a pledge from two individuals who had received the ring from the gemologist. It was held that the gemologist only had the authority to sell the ring for the owner and any other transaction did not affect the owner's interest in the ring. The Court concluded that: "[i]f there be no authority to subject property to a security interest, the creditor has no security interest therein."${ }^{190}$ This was held to be a true consignment situation.

Since the absolute ownership of the property is in the consignor, absent a basis to apply an estoppel (including apparent or ostensible ownership), the consignee has no interest that can be transferred to his creditors or trustee in bankruptcy. ${ }^{\text {II }}$

236 N.W. 2d 299 (Sup. Ct. Iowa 1975) at 305 per Rees J.

See Morton Booth Co. v. Tiara Furniture, Inc., 564 P. 2 d 210 (Sup. Ct. Okla. 1977) [hereinafter Morton Booth].

Rohweder v. Aberdeen Production Credit Ass'n, supra note 67 at 112 per Bright, Cir. J. See also Cain v. Country Club Delicatessen of Saybrook, Inc., 203 A. 2d 441 (Super. Ct. Conn. 1964); In re Sitkin Smelting \& Refining, Inc., 639 F. 2d 1213 (5th Cir. 1981), cert. denied, 645 F. 2d 72. See J.W. Turner, "Rights in Collateral under U.C.C. s. 9-203" (1989) 54 Mo. L. Rev. 677 at 686n. Zions First Nat. Bank v. First Sec. Bank of Ulah, N.A., 534 P. 2d 900 (Sup. Ct. Utah 1975). Manger v. Davis, 619 P. 2d 687 (Sup. Ct. Utah 1980) at 690.

Ibid. at 691 . Note that "commercial consignments" or "consignments" constitute security interests in some PPSAs: Alta., s. 1(1)(qq)(ii)(B); B.C., s. 1(1); Sask., s. 2(nn)(ii); Yukon, s. 1(1).

It is arguable that the terminology used in the Western PPSAs with respect to commercial consignments makes many purchase money security interests relating to goods commercial consignments. This obviously was not intended. The argument is as follows. Alberta's section $1(1)(g)$ says "commercial consignment" means a "consignment" of goods "for sale, lease or other disposition" by a consignor who among other things "reserves an interest in the goods after they have been delivered". (B.C., s. 1(1). The Sask. s. 2(g); and Yukon s. 1(1) definitions of "consignment" are worded somewhat differently.) "Consignment" appears not to have its usual legal meaning of retaining title to goods because of the last clause about reserving "an interest". 
The PPSA does not, however, speak of authority or sufficient interest in collateral in order for a security interest to attach. All that the attachment section requires is that the debtor have an interest ("rights"). Whether under a bailment or a consignment, the debtor does have an interest - even if only one of mere possession. What the courts are conflating in this situation is the "rights" requirement and the derivation principle.

In the context of the closely-held corporation, one has to be particularly careful that the corporation has an interest in personal property in its possession such as will allow it to grant a security interest in the property. There is a duty on the secured party to satisfy himself as to the ability of the corporation to give such a security interest. ${ }^{92}$ Often property in the possession of a closely-held corporation is in fact owned by one of the shareholders. Courts seem to regard this situation as giving the corporation no interest in the collateral such as to satisfy the attachment provisions of the PPSA.

For example, in Zuccarini Importing \& Distrib. Co. Ltd. v. Royal Bank of Canada, Zuccarini entered into what was called a lease of certain restaurant equipment. The document showed the lessee as "Fettuccelle Restaurant" and was signed at the bottom "Fettuccelle Ristorante per B. Fusca". B. Fusca told Zuccarini at the time of ordering the equipment that he was the one who would own and operate the restaurant, though a company had yet to be incorporated. In fact, articles of incorporation for Fettuccelle Restorante \& Pastificio Inc. were already effective at that time. Zuccarini registered a financing statement in the name of Fettuccelle Restaurant, but it was agreed that this registration was defective and so did not perfect any security interest Zuccarini might have. Subsequent to this defective registration, the articles of incorporation were amended to change the name of the corporation to Fettuccelle Ristorante \& Pastificio Inc. There were three shareholders, including B. Fusca. The next year a general security agreement (covering "all property then owned or thereafter acquired") in favour of the bank was executed by Fettuccelle Ristorante \& Pastificio Inc. The bank properly registered its interest. After financial difficulties, the restaurant equipment was seized and an application was made to determine who, as between Zuccarini and the bank, had the better claim to the equipment.

The Court found in favour of Zuccarini. The Court held that there was no conclusive evidence that at some later time the equipment was transferred from Fusca to the restaurant corporation, and that just because the equipment was on the premises of the restaurant corporation, this was not conclusive of ownership. The Court cited Re

\footnotetext{
"Consignment" must therefore have its general meaning of "hand over or deliver to": The Concise Oxford Dictionary, 6th ed. (Oxford: Clarendon Press, 1976). The "interest" reserved appears to be any interest since it is not qualified or narrowed in any way. Therefore, any party who hands over goods to another and reserves an interest in the goods is involved in a commercial consignment. According to paragraph (d) of the definition the transaction is not a "commercial consignment" "if it is generally known to the creditors of the consignee that the consignee is in the business of selling or leasing goods of others." However, if the first part of the definition can be satisfied without the consignor reserving title then the goods are not those "of others" and so the exception will not apply except where the consignor reserves title. 
Country Kitchen Donuts ${ }^{93}$ as authority that in closely-held business corporations, the capital assets are often owned by the individual owners. The Court thought that ownership was the key to the bank's security agreement:

I find that the bank has not proved on the balance of probabilities that the corporation ever acquired title to the equipment. If the corporation acquired no title then the bank could not acquire any security interest in the equipment and is not entitled now to its possession. ${ }^{94}$

Title seems to have been key because the language of the general security agreement gave the bank an interest in all property "then owned or thereafter acquired" by the debtor. Why, however, does the business have to own the collateral before it can give any rights to its secured parties? "Acquired" is not a synonym for "owned" and should refer to the obtaining of any interest in personal property by the debtor. ${ }^{95}$ One gets the sense of a judicial solicitousness to owners of closely-held corporations that defies explanation.

What the courts require beyond mere possession in order to give the debtor an interest is problematic. If there is something other than naked possession then the debtor has acquired such interest as would allow the security interest to attach. If, therefore, the debtor has the right to incorporate the personal property in question into a product for sale, then there is a sufficient interest. ${ }^{96}$ The leading case in this area, where the Court came to this conclusion, is Kinetics Technology, ${ }^{97}$ discussed above. Possession of personal property with the right to work on it is not, however, necessarily sufficient. In Chrysler Corp. v. Adamatic Inc. ${ }^{98}$ a buyer took possession of machines and held them for six months without rejecting them. The Court held that the buyer acquired full title to the machinery and returning the machines to the seller for modifications did not give the seller an interest in the machines that would allow the seller's secured parties to get an interest in the machinery. This case is difficult to distinguish from the Kinetics case. The seller did have the right to possession of the machines with the right to work on them. The seller, therefore, had an interest in the machines. While such an interest might have been of very limited value to the secured party of the seller, that is no

Re Country Kitchen Donuts (1980), 1 P.P.S.A.C. 176 (Ont. S.C.).

Zuccarini Importing \& Distrib. Co. Ltd. v. Royal Bank of Canada (1986), 6 P.P.S.A.C. 46 (Ont. Dist. Ct.) at 50, Haley D.C.J.

That is to say, the phrasing does not say "owned now or hereafter owned by the debtor." This is important generally in PPSA context because it often refers to acquiring or holding rights or interest or property. E.g., the definitions of "consumer goods" and "equipment": Alta., s. 1(1)(h) and (o); B.C., s. 1(1); Man., s. 1; Ont., s. 1(1); Sask., s. 2(h) and (n); Yukon, s. 1(1).

Morton Booth, supra note 87; Litwiller Machine \& Mfg. Inc. v. NBD Alpena Bank, 457 N.W. 2d 163 (CL. App. Mich. 1990); and Amfac Mortgage Corp. v. Arizona Mall of Tempe, 618 P. 2d 240 (Ct. App. Ariz. 1980). 
reason to reach the conclusion that the interest did not exist and therefore the secured party's security interest did not attach. ${ }^{99}$

A debtor can, of course, have a sufficient interest in personal property even though the debtor does not have possession of the collateral. For example, in Re Key National Leasing, the debtor engaged in the business of leasing vehicles. GMAC took a security interest in the vehicles of the debtor "held for lease". The question arose as to whether GMAC had an interest in the vehicles which were leased out by the debtor. In finding for GMAC, the Court said:

It is argued that title is irrelevant under the provisions of the P.P.S.A. and that therefore the words "to be held for sale or lease" must mean holding physically rather than merely holding title. We do not agree. It is true that s. 2 of the P.P.S.A. states that the Act applies to a large number of transactions without regard to form and without regard to "the person who has title to the collateral". That does not mean that title is irrelevant under the P.P.S.A. for all purposes. ${ }^{100}$

Having title is a sufficient interest, even if there is no possession by the debtor.

The existence or absence of possession should, in fact, be of little importance in establishing the existence of an interest. The view that possession (or non-possession) of personal property will lead potential creditors into making financing decisions they would not otherwise make is unrealistic. As Irving A. Gordon contends:

A modem unsecured creditor, however, seldom counts or inspects the property in the debtor's possession before he gives credit. Credit is usually given on the strength of the debtor's financial statements, particularly his profit and loss statement (indicating the debtor's potential to pay the debt from earnings). The creditor also looks at the current ratio and net asset position as shown on the balance sheet to satisfy himself that assets will be available to meet his claims if the seller suffers reverses. In addition, a creditor relies on information from other creditors and from credit agencies as to how the debtor meets his obligations. ${ }^{101}$

Thus, in terms of deciding whether the debtor has an interest in personal property for the purposes of the PPSA, non-possession should not be an obstacle to a positive decision. Nor, however, should "mere possession" be an obstacle. Provided the secured party can get no more than the debtor has to give, there is no conceptual reason why mere possession is not a "sufficient" interest. What the debtor has may be of little value to the creditor, but it is incorrect to conclude that the debtor has no interest, just because the interest is minimal.

On security interests in returned or repossessed goods, see R.H. Skilton \& D.W. Dunham, "Security Interests in Returned and Repossessed Goods under Article 9 of the Uniform Commercial Code" (1981) 17 Willamette L. Rev. 779, and Royal Trust Corp. of Canada v. No. 7 Honda Sales Lid. (1988), 8 P.P.S.A.C. 238 (Ont. Div. Ct.). Corp., supra note 69; Aetna Finance Co. v. Hendrickson, 526 N.E. 2d 1222 (Ct. App. Ind. 1988); and Kendrick v. Headwaters Production Credit Association, 523 A. 2d 397 (Super. Ct. Pa. 1987). I.A. Gordon, "The Prepaying Buyer: Second Class Citizenship under the Uniform Commercial Code Article 2" (1968) 63 Nw. U.L. Rev. 565 at 577-78. 
Under the Western PPSAs, the position is made more clearly in the case of "commercial consignments". ${ }^{102}$ These consignments are deemed security interests ${ }^{103}$ and the PPSAs provide that a debtor has rights in the goods consigned when the debtor obtains possession of them in accordance with the consignment. ${ }^{104}$ The interest of the consignor in a commercial consignment situation must be perfected in order to have priority over (or be effective against) the interests of other parties, such as the trustee in bankruptcy ${ }^{105}$ and holders of perfected security interests. ${ }^{106}$ In the case of the commercial consignment then, mere possession by the consignee certainly gives the consignee "rights" in those consigned goods.

\section{CERTIFICATE OF TITLE}

Many goods, especially movable machinery, can be the subject of certificates of title or regimes to register title. Does the fact that a person has a certificate of title or is registered as owner give that person an interest in the personal property? Cases differ on the appropriate answer.

In General Electric Capital Equipment Finance Inc. v. Inland Kenworth Inc., the Court considered, in relation to the B.C. Repairers Lien Act, ${ }^{107}$ the issue of who is an "owner" of a truck for the purposes of registering a financing statement. ${ }^{108}$ The Court considered that question as similar to that of who is a "debtor" under the PPSA.

The case involved two trucks originally owned by the petitioner. One truck was leased to Mr. Parr with an option for him to purchase it. The other truck was sold to Mr. Parr under a conditional sale. In both cases the petitioner retained title and registered its interest under the PPSA. Mr. Parr operated the trucks as an "owneroperator" affiliated with certain trucking companies. This meant that Mr. Parr or other drivers engaged by him operated the trucks under the direction of a trucking company that would obtain work for the owner-operators. It is the custom in British Columbia for the trucks to be registered in the name of the trucking company, even though it has no beneficial interest in the trucks. Mr. Parr followed this practice. One truck was registered in the B.C. Motor Vehicle Branch in the name of "DCT Chambers Trucking Ltd." and the other truck in the name of "Tri Way Transport Inc."

The various respondents repaired the trucks and were not paid. They all registered financing statements in the Personal Property Registry under the Repairers Lien Act. None of the four financing statements described Mr. Parr or the petitioner as the owner of the trucks. Two of them used the names registered in the B.C. Motor Vehicle

\footnotetext{
102 Called "consignments" in Saskatchewan and Yukon.

103 Supra note 89.

194 Supra note 17.

105 Supra note 32.

lok Alta., B.C., Sask., s. 35(1); Yukon, s. 34(1).

107 R.S.B.C. 1979 , c. 363.

108 General Electric Capital Equipment Finance Inc. v. Inland Kenworth Inc. (1993), 81 B.C.L.R. (2d) 384 (S.C.).
} 
Branch. Two of them used completely different names. The question was which of the financing statements the respondents registered were valid.

The Court noted that the Repairers Lien Act does not assist in interpreting the meaning of "owner". It therefore decided that to reach the proper interpretation of the word "owner", it should consider the purpose of the registration system. The system was intended to provide a mechanism by which parties who may be dealing in goods by way of purchase or security interest can conduct a search to determine what security interests or claims for repairers' liens exist against the owner of the goods. In other words, who would those parties treat as the owner of the trucks in question?

The Court held that a party dealing with a motor vehicle would consider the registered owner of the vehicle to be its owner. The registered owner's name would appear on any transfer documentation and that name would be used to conduct a search. Showing the petitioner's name was, therefore, not necessary to have a valid financing statement. The Court said that the petitioner could have insisted that its name be shown on the certificate of registration along with the trucking company, as is usually the case in British Columbia. Therefore, the two financing statements that used the name of the registered owner trucking company as the owner of the trucks were valid. The other two were not.

The decision does not say what would have happened if the respondents had used the name of the petitioner or Mr. Parr as owner. Surely the use of those names could not invalidate financing statements. But they are not the names to be found in the B.C. Motor Vehicle Branch. This case shows that "owner" can have different meanings depending on the context. It appears that the registered owner (even if he is not the actual owner) can have an interest in collateral which allows a repairer to register against his name for the purposes of perfecting the repairer's lien. By analogy then, and keeping in mind the equation the court made between the Repairers Lien Act and the $P P S A$, this decision should mean that a debtor who is the registered owner of personal property (even if she is not the actual owner) has a sufficient interest in the property to give a secured party a security interest in it.

On the other hand, in the U.S., mere possession of a certificate of title has been held insufficient to give its holder an interest in the personal property. According to the Court in Matter of Emergency Beacon Corp., "[w]e are aware of no authority ruling that a security interest could attach, to a vehicle that the debtor had already sold, simply because the certificate of title had not been transferred." ${ }^{109}$ In Texas State Bank v. Foremost Ins. Co., ${ }^{110}$ Goodbar was indebted to the bank and had given as security an interest in all new and used mobile homes owned or purchased by Goodbar. Goodbar purchased a mobile home and delivered the manufacturer's certificate of origin to the bank. The certificate was not endorsed to Goodbar or, in fact, to anyone except Foremost, the original assignee, who had no knowledge of the dealing between the bank and Goodbar. The bank argued that it had a valid security interest in the mobile home 
because it had possession of the mobile home and of the original manufacturer's certificate. It argued that Foremost should not have permitted the 'manufacturer's certificate of origin to go into Goodbar's hands. The Court of Civil Appeals of Texas disagreed. It held that in order for the bank to prevail, the debtor (Goodbar) must have rights in the collateral. The certificate of origin was never endorsed to Goodbar and was not an "open" or "negotiable" document. Therefore, Goodbar could never obtain an interest in the certificate of origin. The Court concluded that: "[w]e hold that no one can give a valid security interest in such property unless he has rights in the collateral."111

Problems involving certificates of title or registration of title will often arise in the context of spouses where one spouse buys property in the name of the other. In GMAC v. Washington Trust Co. of Westerly, where the husband paid a $\$ 1,400$ down payment and executed the installment sales contract for the purchase of a car, it was held that the husband had an interest in the car for the purposes of attachment of a security interest in the car, notwithstanding that the wife was the registered owner of the car and held title to it. ${ }^{112}$ However, this should be compared to Matter of Bosson, ${ }^{113}$ where the opposite result was reached. With a husband and wife, the Court said, there is a presumption of a gift. In such a case there is no presumption of a resulting trust as there usually would be where A buys an item from B and directs that title be vested in C. At most, in this case, the husband's interest was only a right to deliver the car to his wife. A similar result held in Majors v. Majors, where the wife of the execution debtor claimed that the debtor's car was her property by virtue of a resulting trust on the basis that she had paid for the car and put the title in the husband's name only for convenience. ${ }^{114}$ The Court rejected this argument saying that there was no express understanding that the debtor was to hold the car in trust for his wife. ${ }^{115}$ In these cases, the courts take a stance of all-or-nothing. The only interest considered is outright ownership. Anything short of this appears not to be a sufficient interest for the purposes of the attachment sections of the PPSA, which is a peculiar result and adds a limitation to the Act which is not there.

\section{E. PRODUCTION QUOTA OR LICENCE}

The situation with respect to agricultural production quotas and other licences is similarly unclear. In National Trust Co. v. Bouckhuyt ${ }^{116}$ the question arose of whether a "basic production quota" (BPQ) - that is, a government quota to grow tobacco constituted property of the debtor which it could use as collateral for its secured parties. The Ontario Court of Appeal held that it did not. The Court said that although the BPQ could be leased, and, in a "peculiar" form could be transferred and pledged, its basic nature was such that all transactions pertaining to the $\mathrm{BPQ}$ were subject to the

III Ibid. at 654.

112386 A. 2d 1096 (Sup. Ct. R.I. 1978).

113432 F. Supp. 1013 (D.C. Conn. 1977).

$114 \quad 37$ A. 2d 528 (Sup. Ct. Pa. 1944).

115 See also Clearfield State Bank v. Contos, 562 P. 2d 622 (Sup. Ct. Utah 1977).

116 (1987), 7 P.P.S.A.C. 273 (Ont. C.A.), rev'g (1987), 7 P.P.S.A.C. 113 (Ont. H.C.J.) [hereinafter Bouckhuyt]. 
unfettered approval and discretion of the Tobacco Board. The BPQ merely represented the granting of a privilege and could not, therefore, be considered to be property, as indicated by Cory J.A.:

The notion of "property" imports the right to exclude others from the enjoyment of, interference with or appropriation of a specific legal right. This is distinct from a revocable licence, which simply enables a person to do lawfully what he could not otherwise do. ${ }^{117}$

The Court held that although the BPQ might be sold in a limited market, the mere fact that it could be exchanged, sold, pledged, or leased did not in itself make it property; it did not fall within the definition of intangible personal property. Therefore, National Trust (the creditor) could not get a security interest in it.

The Ontario Court of Appeal considered the question of milk quotas as property in $C I B C$ v. Hallahan. ${ }^{118}$ There, the Court refused to overrule the decision in Bouckhuyt by concluding that "[t]his appeal does not raise the identical issues as in Bouckhuyt, but unfortunately the statements made by the Court as to what constitutes personal property are broad enough to determine them." 119 The Court went on to say that it thought Bouckhuyt should be reconsidered because

[T]he Court placed too much emphasis on traditional definitions of personal property and did not give enough consideration to the realities of commercial transactions within the regulatory framework of a modern farm products marketing scheme. ${ }^{120}$

However, the Supreme Court of Canada refused to take up the matter. ${ }^{121}$

A different result was obtained in Saskatoon Auction Mart Ltd. v. Finesse Holsteins, where the Court held that a milk quota was intangible personal property and its holder could, therefore, give a security interest in it. The Saskatchewan Court of Queen's Bench alluded to the Bouckhuyt case and the criticism which followed in refusing to apply it, as Matheson J. indicated:

As Professor McLaren has pointed out in his annotation to Bouckhuyt ... the holder of an agricultural marketing quota has both the right to produce and to market the agricultural product. Consequently, even if the allotting of a quota is viewed initially as a mere licence at common law, the additional rights must be considered to be a grant. A licence with a grant creates rights of property. ${ }^{122}$

The judge also noted the value of the asset to a dairy producer. However, in Sanders v. British Columbia (Milk Board), ${ }^{123}$ the Court held that the forced surrender upon 
transfer of a percentage of a milk quota did not constitute expropriation without compensation because the milk quota was not property. Relying on Bouckhuyt, the court said that the milk quota was a situation where "the Board giveth and the Board taketh away." ${ }^{124}$ A similar result held in Bank of Montreal v. Bale, ${ }^{125}$ where the court thought that the Bouckhuyt and Hallahan decisions made it "clear that a milk quota is not property within the meaning of the PPSA and accordingly, cannot be the subject-matter of a security agreement.".126

In Re Foster, ${ }^{127}$ the Court dealt with whether a taxi licence was property which could be used as collateral. Lane J. concluded that:

There is no hard and fast rule as to the nature of a business or professional licence. It appears that the characterization of such a licence depends on the extent to which the licence holder can be said to have been granted a vested right on the one hand; or a privilege wholly dependent on the discretion of the issuing Ministry or regulatory body on the other hand. ${ }^{128}$

The Court said that in Bouckhuyt, the BPQ only conferred a right to apply annually for a new licence. That right was too transitory and ephemeral to be considered property. In the case of a taxi licence, however, the Court examined the relevant legislation and regulations and found that there was a prima facie right to renew the licence. It was also significant that the licence was recognised as an asset of the estate of a deceased holder. Therefore, it was not too transitory and ephemeral a privilege to be property.

In government-issued licences then, the key to whether the holder has an interest is whether the licence can be transferred and be of any value beyond the article it is written on. Lane J., in Re Foster, describes the situation as follows:

\footnotetext{
What this case law reveals is a tension between the commercial reality that licences, like any commodity in restricted supply, have a value that may be traded, and the legal impact of the legislator's desire to maintain, in varying degrees, control over the industry in question. Where the control is absolute and unfettered, no property interest exists even though there is a market: Bouckhuyt; Sanders; where there is a market and a practical, historical assurance of renewal, the licensee has a right akin to a chose in action, and hence property: Johnson; Ackerman. ${ }^{129}$
}

The value of the licence is greatly reduced if the holder does not have the power to transfer it. ${ }^{130}$ Many such licences are personal to the holder; the holder often has to

Ibid. at 614, per Macdonald J.A. See, similarly, Ackerman v. Nova Scotia (Attorney-General) (1988), 47 D.L.R. (4th) 681 (N.S.S.C.). On the position with respect to fishing licences, see Johnson v. Ramsay Fishing Co. (1988), 47 D.L.R. (4th) 544 (F.C.T.D.) and Re Bennett (1988), 24 B.C.L.R. (2d) 346 (S.C.).

12s (1991), 5 O.R. (3d) 155 (Ont. Gen. Div.).

$126 \quad$ Ibid. at 160.

127 (1992), 89 D.L.R. (4th) 555 (Ont. Gen. Div.).

128 Ibid. at 560.

$129 \quad$ Ibid. at 566.

130 Sanford, supra note 66 at $188-90$. 
do some test to get the licence, for example a driver's licence. ${ }^{131}$ The licence does not give the holder an interest because it does not give him a (Hohfeldian) power to do anything; it simply gives the holder a privilege. ${ }^{132}$ In such situations, it cannot be property in which the debtor has an interest for the purposes of the PPSAs because any security interest given in it could never be of any value to the creditor. There is no correlative duty or liability on anybody as a result of the debtor's holding the licence, so it cannot be said that the licence gives the debtor a right or a power. The Finesse Holsteins and Bouckhuyt situations were different in that there was more than a mere licence involved. The Court in Bouckhuyt even acknowledged that in some circumstances the BPQ could be dealt with. It accorded the holder some powers, and therefore should have been viewed as property in which the holder had an interest.

\section{F. TRUE LEASE}

For the purposes of the PPSA, it is necessary to distinguish a true lease from a security lease. ${ }^{133}$ A security lease is typically a conditional sale dressed up as a lease. In a security lease, unlike a true lease, the "lessor" does not intend to get the "leased" goods back, at least so long as they have any useful life left. The security lease is a type of security agreement which is governed by the PPSA. However, whether the debtor gains access to personal property by means of a true lease or a security lease, there is an interest in the property to satisfy the requirements of the attachment section. In some U.S. cases, however, there appears the idea that third parties cannot take rights in the leased collateral through the debtor/lessee where the lease involved is a true lease.

In Towe Farms there was a lease of cows to a farmer. A financier of the farmer, who had taken a security interest in all of the farmer's livestock and proceeds, repossessed and sold the cattle. The Court held that the lease was a true lease; one of the factors the court took into account was that the lessor "intended to retain title in and protect their original investment." ${ }^{134}$ The Court thought that a true lease was not a transaction of purchase and therefore, "does not confer even voidable title upon the lessee." 135 The Court appeared to be looking for some sort of status as purchaser in order for the lessee to confer some right or interest on the financier.

At least one American case distinguished the situation of a true lease (giving, it would seem, no rights to the lessee that could go to the secured party) from the situation of the true lease with an option to purchase (which did give the lessee such

However, note Re Gill and Registrar of Motor Vehicles (1985), 21 D.L.R. (4th) 202 (Ont. C.A.), where the Court decided that a driver's licence was property. It is questionable whether the Court would have reached the same conclusion in the context of the PPSA. home licence was not property that could be mortgaged. See also Re Restfulcare Inc. and Regional Assessment Commissioner (1986), 53 OR (2d) 673 (C.A.). 
rights). In Empire Machinery Co. v. Union Rock \& Materials Corp., ${ }^{136}$ the lessee had an option to purchase a caterpillar motor grader. The Court held that an option to purchase, when exercised, gave rise to a property right in which the lessee could create a security interest. The UCC did not require that the debtor have rights in the collateral at the time the security agreement was made. The security interest could attach to the collateral at a later date, in this case when the option to purchase was exercised. The implication is that the lessee had no interest in the collateral before that option was exercised, or at least an insufficient interest, for the purposes of the attachment provision.

As discussed above, there is no reason to exclude leased personal property from collateral in which the debtor has an interest. Nothing in the PPSA prevents the lessee from encumbering the interest which she has under the lease. ${ }^{137}$ The lessee's interest might not be very extensive and there may be a default under the lease if a secured party of the lessee ever took possession of the personal property leased, but these factors do not detract from the fact that the lessee does have an interest in the leased property. ${ }^{138}$ There is no theoretical reason why there should not be permitted security interests in leased property. The lessor can put default provisions in the lease to guard against the lessee's secured party taking possession of the property. In any event, the secured party could only get what the lessor had, and would be obliged to make rental payments and comply with whatever other terms of the lease the lessee was subject to.

These protection devices for the lessor are unavailable, however, where (as in the Western PPSAs) a lease for a term of more than one year is deemed a security interest, ${ }^{139}$ which must be perfected to have priority over or be effective against the interests of other parties, such as the trustee in bankruptcy ${ }^{140}$ and holders of perfected security interests. ${ }^{141}$ The deeming of leases for a term of more than one year to be security interests makes it inferentially clear that the debtor must be taken to get an interest in the leased property, even in the case of a true lease. To make this point absolutely clear, the Western PPSAs specifically provide that the debtor has rights in goods leased to the debtor when he obtains possession of them in accordance with the lease. $^{142}$

579 P. 2 d 1115 (Ct. App. Ariz. 1978).

See J.J. White \& R.S. Summers, Uniform Commercial Code, 3d ed. (St. Paul, Minn.: West, 1988) at 987.

Note that in Paccar Financial Services Ltd. v. Sinco Trucking Lid. (Trustee off (1989), 57 D.L.R. (4th) 438 (Sask. C.A.) the Court held that the definition of "property" in s. 2 of the Bankruptcy Act was broad enough to take into account a leasehold interest.

Alta., s. 1(1)(qq)(ii)(c); B.C., s. 1(1); Sask., s. 2(nn)(iii); Yukon, s. 1(1).

Supra note 32.

Supra note 106.

Supra note 17. 


\section{G. FUTURE PROPERTY}

The PPSA allows for security interests in future or after-acquired property. ${ }^{143}$ The secured party cannot have an interest in this property before the debtor has an interest herself. But, as soon as the debtor has such an interest, there is no further step required to pass that interest on to the secured party. Care must be taken not to confuse an interest in property which is not yet in existence with an interest in property which will entail payment at a future date. In the latter case, the interest of the secured party arises immediately because the debtor has an interest in existing property which will generate revenue or payment in the future. Thus, an assignment of existing book debts gives an immediate interest to the secured party, even though there may be no payment until a future date.

In Royal Bank v. The Queen, ${ }^{144}$ it was held that an assignment of book debts registered under the PPSA conveyed all property in the debts to the secured party. From the date of the assignment the book debts ceased to be the property of the debtor and any money received by the debtor would be held in trust for the secured party. Thus, such funds were not available to Revenue Canada to satisfy its claims against the debtor. To the court the matter was a simple one of ownership; "the assignee owns the book debts and the assignor does not." ${ }^{145}$

Another similar situation is a right to payment pursuant to a contract. The property is in existence as soon as the right arises, even if the satisfaction of the right (that is, payment) is in the future. Thus, when contracts for the installation of carpets were created (that is, when rights to payment for services were established), whether conditionally or absolutely, property of an incorporeal nature came into existence and a security interest could attach to it. ${ }^{146}$ The right to payment for services rendered is property in existence, as Warriner Dist. Ct. J. contends:

An existing right to property (in this case a contractual right to receive money for services to be rendered) is itself property in existence under the Act. It matters not that fruition of the right is in futuro or conditioned upon a corresponding duty on the part of the holder of the right. The subject of the right, that is, the money to be received for services to be rendered is part and parcel of that right at the time the right is created (in this case when the contracts were entered into) regardless of when the money is actually to be paid or when the right thereto becomes absolute..... ${ }^{147}$

Alta., s. 13; B.C., s. 13; Man., s. 13; Ont., s. 12; Sask., s. 13; Yukon, s. 12. (1984), 4 P.P.S.A.C. 131 (F.C.T.D.), aff'd (1986), 6 P.P.S.A.C. 44 (F.C.A.).

Jbid. at 146 per Muldoon J. One has to look carefully to the agreement between the creditor and the debtor to ascertain when the creditor's rights arise. In Re McAvoy (1988), 8 P.P.S.A.C. 261 (Sask. Q.B.), a mortgage provision giving the creditor a right on default to take possession of the land and collect rents was not broad enough to constitute an assignment of rents. Cf. United Dominions Investments Lıd. v. Morguard Trust Co. (1985), 5 P.P.S.A.C. 8 (Sask. Q.B.). On the issue of rights in chattel paper, see T.H. Jackson, "Embodiment of Rights in Goods and the Concept of Chattel Paper" (1983), 50 U. Chi. L. Rev. 1051.

Pine Builders, Inc. v. U.S., 413 F. Supp. 77 (D.C. Va. 1976).

Ibid. at 82 per Warriner, Dist. J. 
Care will have to be taken, however, to ensure that a debtor does in fact have a right to payment, at present or in the future. ${ }^{148}$

\section{THE DEPENDENCY OF INTERESTS: THE DERIVATION PRINCIPLE AND ITS EXCEPTIONS}

The nature of the debtor's interest in personal property will be important because in some cases it will determine the extent of the secured party's interest in the collateral. The common law principle is that one interest is derived from another. One who derives one's interest from another can be given no more than that other has to give: nemo dat quod non habet. ${ }^{149}$ This basic idea, the principle of derivation, is not abolished by the PPSA. No section of the PPSA specifically preserves the derivation principle however, so it must come in as a result of the general principles of common law and equity that continue to apply insofar as they are not inconsistent with the provisions of the Act. ${ }^{150}$ Thus in Bouckhuyt, in the context of whether a security interest could be granted in a tobacco production quota, the Court concluded:

The Atkinsons could not grant to National Trust more than they possessed.... There was no magical means by which the limited contractual right or privilege which the Atkinsons possessed could be converted into a property interest contrary to the very conditions under which the quota was granted to the Atkinsons and under which they held it. ${ }^{151}$

It must be stressed, however, that the derivation principle is very much residual in the $P P S A$ context. That $A c t$ is based to a large extent on the idea of ignoring title and altering common law resolutions as to entitlement to personal property. The PPSA makes it clear that security interests can exist in collateral without regard to the person who has title to the collateral. ${ }^{152}$

As has been discussed, it is the derivation principle which gives some protection to other interest holders from having their interests in personal property curtailed or otherwise affected when the debtor grants a security interest in that property to her creditors. It is this principle which, in a sense, adds the qualification "sufficient" to a debtor's interest in personal property, not the attachment section. As was discussed earlier, there is no reason why in general a lessee cannot give an interest in leased property to a third party, such as a secured party. The lessee does have an interest in the leased property. Absent a statutory provision to the contrary (as in the provision in some PPSAs with regard to leases for a term of more than one year), ${ }^{153}$ however, the derivation principle says that the secured party can get at most only what the lessee

See Weld Colorado Bank v. E \& E Const. Inc., 653 P. $2 d 758$ (Ct. App. Colo. 1982).

J. Burke, Jowitt's Dictionary of English Law, 2d ed. (London: Sweet \& Maxwell, 1977) at 1229 cites D. Jenkins, Eight Centuries of Reports (1734) as an early example of the use of this principle. It goes back much further: See Sir Holdsworth, supra note 1 at 510 .

Alta., s. 66(3); B.C., s. 68(1); Man., no equivalent; Ont., s. 72; Sask., s. 64(5); Yukon, s. 63(1).

Supra note 116 at $286-87$.

Supra note 70.

Alta., s. 1(1)(qq)(ii)(C) and s. 3(2); B.C., s. 1(1) and s. 3; Sask., s. 2(nn)(iii) and s. 3(b); Yukon, s. $1(1)$ and s. $2(b)$. 
had, that is, a limited right to use the leased property upon payment of rent and satisfaction of any other conditions of the lease. In a jurisdiction without the provision as to leases for a term of more than one year being deemed security interests, if the secured party were to take possession of the leased property, it might find itself with a valueless property because taking possession triggered a default provision in the lease entitling the lessor to repossess the property. The expiration of the lease due to default or otherwise would terminate the lessee's interest under the lease, and so it must also terminate the secured party's interest in the leased property. ${ }^{154}$ Even if there were no repossession by the lessor, the secured party might find that leased property is not worth seizing, given the rental payments that might have to be made. ${ }^{15 s}$ However limited or valueless the secured party's interest might be in the lease situation, it is not correct to say that the secured party can get no interest in property leased by the debtor. The secured party gets what the debtor had to give. It is true that the PPSA indicates that a security interest can be created in collateral regardless of the person who has title to the collateral, but this does not mean that the person who has title does not continue to have rights. The PPSA could take those rights away, as it does for example in the Western PPSAs, if a lessor has not perfected its interest under a lease for a term of more than one year which has been deemed a security interest, and there is a competing interest of the trustee in bankruptcy. But absent such a provision, the secured party's interest will be affected by the derivative principle.

This same principle affects not only the existence of a secured party's interest but the timing of the secured party's interest. A secured party will often receive an interest in after-acquired property. A security interest cannot attach to after-acquired property until the debtor herself has an interest in the collateral. If there has been an agreement that it attach, and value has been given, the security interest attaches when the debtor acquires such interest - for example in an account when it comes into existence. ${ }^{156}$ It is common for a security agreement to be entered into before the debtor has an interest in the property. In National Trailer Convoy of Canada Ltd. v. Bank of Montreal, the Court held that "[t]he subsequent acquisition by a debtor of an interest feeds the security of the secured party." 157

The rule nemo dat quod non habet is too restrictive in many situations and has been the subject of many modifications. Courts acknowledge that there may be "special circumstances" which allow a secured party to get an interest greater than that the debtor had. ${ }^{158}$ To do so, the secured party must find an applicable rule of substantive law which endows him with those rights. We have already seen that the voidable title of the debtor is sufficient to confer a good title on the secured party. The most usual source of exceptions will be the PPSA.

$134 \quad$ Bodnard v. Capital Office Systems Inc. (1992), 3 P.P.S.A.C. (2d) 71 (Sask. C.A.).

iss See D.G. Baird \& T.H. Jackson, Cases, Problems, and Materials on Security Interests in Personal Property, 2d ed. (Mineola, New York: Foundation Press, 1987) at 169-70. 
The PPSA itself expands on interests. In a sense, the PPSA is about giving interests to creditors that they would not receive through the common law. ${ }^{159}$ The PPSA does this by insisting on perfection in order to assure the priority of a security interest. If a security interest is unperfected then a subsequent secured party who does perfect his security interest in the same collateral has priority for that security interest over the previous one, even if he has knowledge of it. The second secured party is taking an interest the debtor does not have to give. ${ }^{160}$ Sometimes the PPSA can enhance an interest in more specific ways. As has been mentioned, in the Western PPSAs, in some situations a secured party can take an interest in leased or consigned personal property greater than the lessee or consignee had to give, if the lease or consignment is one deemed to be a security interest and the interest of the lessor or consignor has not been perfected in the requisite time. ${ }^{161}$ In these situations, the residual priority rule states that the perfected security interest has priority over the unperfected security interest (that is, that of the lessor or consignor). ${ }^{162}$

One of the principal provisions in the PPSA which derogates from the derivation principle is $\mathrm{s} .20{ }^{163}$ which either subordinates or makes ineffective unperfected security interests as against the listed interests and individuals. The most significant

In the Western PPSAs, section 35 is the major section governing the priority of security interest. In those PPSAs, that section sets out a rule to preserve the derivation principle in the two-debtor situation: Alta., s. 35(7); B.C., s. 35(8); Sask., s. 35(6); Yukon, s. 34(6). For a discussion of this issue, see Alberta Personal Property Security Act Handbook, supra note 60 at 267-69; British Columbia Personal Property Security Act Handbook, supra note 60 at 268-70. The need to preserve the derivation principle in this circumstance is an acknowledgement that the rest of $\mathbf{s .} 35$ may work to disturb it, at least to some extent.

It is important to remember that these statutory exceptions to the derivation principle do not necessarily affect the rights of the original two parties. For example, failure to perfect a security interest, though it can have a drastic effect on the secured party vis-à-vis third parties, does not affect the obligations of the parties to an instrument inter se: Fotti v. 777 Management Inc. (1981), 2 P.P.S.A.C. 32 (Man. Q.B.).

161 See definition of "security interest" and the deeming provision in Alta., s. 1(1)(qq) and s. 3; B.C., s. 1(1) and s. 3; Sask., s. 2(nn) and s. 3(b); Yukon, s. 1(1) and s. 2(b). See also the section dealing with sales to a buyer in the ordinary course of business: Alta., s. 30; B.C., s. 30; Man., s. 30; Ont., s. 28; Sask., s. 30; Yukon, s. 29.

A further example of the PPSA enhancing rights was discussed in Tureck v. Hanston Investments Lid. (1986), 5 P.P.S.A.C. 210 (Ont. H.C.J.), where the Court said that a pledgee of shares at common law did not have title to the shares pledged and had no right to retain or foreclose upon the pledged security upon default. His remedy was to sell the pledged property. The Court held, however, that the PPSA enhanced that status by giving the pledgee increased remedies including a limited right to foreclose.

Supra note 106. It is not clear, however, just what it means to say that the perfected security interest has priority over the unperfected interest of the lessor or the consignor. Part 5 of the PPSA does not apply to true leases and consignments, even if they are leases for a term of more than one year or commercial consignments: Alta., s. 55(1); B.C., s. 55(1)(a); Sask., s. 55(1); Yukon, s. 53(1). It is Part 5 of the PPSA that gives the idea of "priority" its practical meaning. Although the PPSA does not explicitly say so, priority for the perfected security interest must mean that the unperfected interest of the lessor or the consignor is not effective against it. This is made clear in the s. 20 (Yukon, s. 19) context which explicitly subordinates or makes ineffective unperfected security interests (including those of lessors or consignors) as against the listed interests and individuals. 
beneficiary of this provision is the trustee in bankruptcy. In Bell's Dairy Ltd., the Saskatchewan Court of Appeal concluded that the interest of a trustee in bankruptcy to a truck that had been leased to the debtor could be greater than the interest of the debtor. The lessor's interest in the truck was unregistered. The Court held that the trustee in bankruptcy took priority to the truck over the lessor. Cameron J.A. said:

It is also true, as a matter of common law, that under a contract of bailment the bailee derives a right to possession only, with title remaining in the bailor. And it is correct to say that $\mathbf{5 . 2 0}$ of the Personal Property Security Act is aimed at ranking and not conferring interests. With the utmost respect, however, these general propositions do not sustain the conclusion reached in the Ford Credit case. I say that having regard, first, for the scope of the enactment, second, for the structure of the section in issue and, finally, for the true nature of the office of a trustee in bankruptcy. All suggest that the trustee's claim must prevail. ${ }^{164}$

He continued:

I fail to see any legitimate basis for confining [the trustee in bankruptcy] to no greater claim upon the goods than that which the bankrupt enjoyed. That would require resort to traditional common law concepts, to form over substance, to a technical construction of the term "interest", and to the defeat of the policy choice made by the legislature in choosing, as it did, to include within the scope of the Act a true lease of goods. ${ }^{165}$

In Donaghy v. CSN Vehicle Leasing, the Alberta Court of Queen's Bench adopted the Saskatchewan Court of Appeal approach in Bell's Dairy Ltd., with respect to the trustee in bankruptcy. It was held that section 20(1)(b) of the Alberta PPSA means "an unperfected lessor will lose his common law right of ownership to a trustee in bankruptcy." 166

A narrow view of the trustee in bankruptcy's interest was set out in Maliteare v. Royal Bank of Canada. There, the Bank registered a security interest in a mobile home in Manitoba, but when the debtor moved to Saskatchewan with the mobile home, the Bank did not re-register in Saskatchewan in time to have continuity of perfection before the debtor declared bankruptcy. The debtor sought an order exempting the mobile home from seizure from the Bank. This was possible under the Exemptions $A c t^{167}$ if the debtor was a execution debtor. The Court held, however, that the debtor was a debtor under a security agreement. The Bank's security interest was unperfected but it was still a security interest. According to the Court, the trustee in bankruptcy could get no higher interest in the collateral than that of the bankrupt, as Geatros J. indicated:

There are no circumstances whereby it can be said that the rights of the trustee to the mobile home are higher than that of the bankrupt, the applicant. At the material time the respondent's security interest

Bell's Dairy Ltd., supra note 26 at 168.

Ibid. at 173.

Donaghy v. CSN Vehicle Leasing (1992), 4 Alta. L.R. (3d) 40 (Q.B.) at 45 per Virtue J.

R.S.S. 1978 , c. E-14. 
was still in place. That it was then unperfected did not give to the trustee an "interest" to which the respondent's interest is subordinated. ${ }^{168}$

As is clear from the discussion with respect to voidable title, not all exceptions to the derivation principle need be statutory. ${ }^{169}$ A debtor may have a sufficient interest in personal property for the purpose of granting an enforceable security interest if the true owner of the collateral has agreed to such use by the debtor, or is otherwise estopped from denying the creation or existence of the security interest. ${ }^{170}$ According to the Court in Matter of Pubs, Inc. of Champaign:

[T] he debtor may clearly have sufficient "rights" for the purposes of s. 9-203 if the true owner of the collateral has agreed to the debtor's use of the collateral as security or if the true owner has become estopped to deny the creation or existence of the security interest. ${ }^{171}$

In Pontchartrain State Bank v. Poulson, when an owner lent equipment to a debtor with the understanding that the debtor had the option to buy, the Court held that the debtor might be estopped from denying property rights in the collateral if the true owner failed to notify the secured party of the debtor of the true owner's identity. ${ }^{172}$ Note here the odd conception of estoppel. It was the debtor that the Court said could be estopped by virtue of another's failure to inform. ${ }^{173}$

Estoppel, of course, has its limits. In First Southern Ins. v. Ocean State Bank, although the case recognized the principle, it was held that to be estopped from denying the validity of a security interest in his car given by another, the owner of the car must do more than simply entrust the car to an employee who wrongfully and without authority altered the title documents to have them indicate that he was the owner. The Court held:

Where the owner of property knowingly cloaks another with indicia of ownership or authority over the property, the owner will be held to have represented such ownership or authority to third parties.

Maliteare v. Royal Bank of Canada (1987), 7 P.P.S.A.C. 160 (Sask. Q.B.) at 164. See also Re Perepeluk, [1986] 2 W.W.R. 631 (Sask. C.A.).

Other provisions in the PPSA which derogate at least to some extent from the derivation principle include: the residual priority rule: Alta., s. 35; B.C., s. 35; Man., s. 35; Ont., s. 30; Sask., s. 35; Yukon, s. 34; the proceeds provision: Alta., s. 28; B.C., s. 28; Man., s. 27; Ont., s. 25; Sask., s. 28; Yukon, s. 26; the section protecting buyers and lessees in the ordinary course of business: Alta., s. 30; B.C., s. 30; Man., s. 30: Ont., s. 28; Sask., s. 30; Yukon, s. 29; the fixtures and accessions provisions: Alta., s. 36 and s. 38; B.C., s. 36 and s. 38; Man., s. 36 and s. 37; Ont., s. 34 and s. 35; Sask., s. 36 and s. 37; Yukon, s. 35 and s. 36. See B. MacDougall, "Fixtures and the PPSA: of the Wooden Horse of Troy, Creditors in the Weeds and Statutory Ambush" (1993) 72 Can. Bar Rev. 496.; the provision on transfer of the debtor's interest in the collateral: Alta., s. 51; B.C., s. 51; Man., s. 50; Ont., s. 48; Sask., s. 49; Yukon, s. 45.

Arco Delta Corp. Canada Ltd. v. U.S., 459 F. $2 d 436$ (7th Cir. 1972); Northwestern Bank v. First Virginia Bank of Damascus, supra note 158.

Matter of Pubs, Inc. of Champaign, 618 F. 2d 432 (7th Cir. 1980) at 436 per Cudahy, Cir. J. 684 F. 2d 704 (10th Cir. 1982). See also Security State Bank of Wewoka v. Dooley, 604 P. 2d 153 (Ct. App. Okla. 1979).

In this case the Court did not have to decide the issue finally because the other requirements of a valid security interest were not satisfied. 
Under such circumstances, the doctrine of estoppel will preclude the owner from complaining where a third party relies upon such representation to his detriment. But the doctrine does not apply where the indicia of ownership is not knowingly given by the true owner, such as where it is secured by thef, forgery or other criminal act. ${ }^{174}$

\section{CONCLUSION}

The great merit of the PPSA is its completeness and its insistence on substance over form. It is part of a long movement away from a primitive legal equation of interest with possession. It gives as many people as possible interests in personal property and allows those interests, in conjunction with market forces, to be used to generate wealth for as many people as possible. It eschews artificial impediments to this goal, such as requiring a debtor to have title, or requiring the property interest to be in existence at the time of the security agreement, or requiring a particular form of agreement. Likewise, the PPSA should be interpreted so as to avoid complexity when it comes to issues relating to the interest of the debtor in personal property. The Act itself appears to make matters complex by virtue of the terminology it uses. As this article suggests, there is no difference between an interest and rights in personal property. This article suggests the use of the former term, but only because it gives the appearance of being a less laden, more generalized term, not because there is anything "wrong" with the use of the term "right". The PPSA imposes no explicit qualification that an interest of a debtor be "sufficient" to allow attachment of a security interest. Any interest (or right) should be adequate. The derivation principle will, in some cases, ensure that the secured party gets no greater interest than the debtor had to give. In some instances, the PPSA explicitly deviates from the derivation principle and there are well recognized exceptions in the cases of voidable title and estoppel. On the whole, however, the PPSA operates to allow both preservation and proliferation of interests in personal property. Keeping these principles in mind helps ensure an effective and efficient system of security. 